Article

\title{
Science Mapping of Tourist Mobility 1980-2019. Technological Advancements in the Collection of the Data for Tourist Traceability
}

\author{
Angela Chantre-Astaiza ${ }^{1, *,+}$, Laura Fuentes-Moraleda ${ }^{2}$ and Ana Muñoz-Mazón ${ }^{2}$ \\ and Gustavo Ramirez-Gonzalez ${ }^{3}$ D \\ 1 Departamento de Ciencias del Turismo, Universidad del Cauca, Popayán 190001, Colombia \\ 2 Vicalvaro Campus, Rey Juan Carlos University, Paseo Artilleros sn, 28032 Madrid, Spain \\ 3 Departamento de Telemática, Universidad del Cauca, Popayán 190001, Colombia \\ * Correspondence: achantre@unicauca.edu.co; Tel.: +57-2-8209-800 \\ † Current address: Calle 5 4-70, Popayán 190001, Colombia.
}

Received: 14 July 2019; Accepted: 24 August 2019; Published: 30 August 2019

\begin{abstract}
The tracking of tourist movements is an essential aspect in the management of sustainable tourist destinations. The current information and communication technologies provide innovative ways of collecting data on tourist movements, but it is still necessary to evaluate tools and methods of study for this challenge. At this point, mobile technologies are the best candidate for this task. Given the relevance of the topic, this paper proposes a mapping science analysis of publications on "movement of tourists" and "traceability." It has been carried out in the two main sources WOS and SCOPUS. The term "traceability" is brought from industry and technology areas to be applied to the tourist movement/mobility tracking and management. The methodological scheme is based on a selection of search criteria with combinations of terms. The sources of specialized information in applied social sciences and technology were then selected. From there, the searches have been executed for their subsequent analysis in three stages-(I) relevance analysis filtering the results to obtain the most pertinent; (II) analysis of articles with similarity thematic, authors, journals or citations; (III) analysis of selected papers as input for the mapping analysis using Citespace. The automatic naming of clusters under the selected processing confirms that the analysis of movements is a valid scientific trend but research-oriented from the perspective of traceability is non-existent, so this approach is novel and complementary to existing ones and a potential contribution to knowledge about tourist movements. Finally, a set of methodological considerations and a classification of information capture tools are proposed. In this classification, mobile technology is the best option to enable tourist movement analysis.
\end{abstract}

Keywords: tourist movements; traceability; science mapping; tools; citespace; review; bibliometric; planning; pedestrian; mobile; technology

\section{Introduction}

From the sustainability point of view, the study of tourist movements as part of tourist behavior allows us to understand the movement of people through space and time. This concept is currently of high interest as a potential income for planning and control and also to allow better optimization of their carrying capacity and an improvement in the use of resources, facilitating both their management and their organization with its impact on sustainability. This impacts on transport and the available infrastructure; also the functions of seasonality and the maximum use of the resources generated by the visits. According to the work of Tiwari, Kaushik and Jagwani [1,2], the information obtained from the studies of tourist movements is useful for the analysis of carrying capacities, for traffic 
planning, as well as for locating advertising and planning itineraries. The origin of this type of studies goes back to 1933 when Ogilvie envisioned the necessity of the study of tourist movement for future investigations in tourism. However, it was in the 1990s, when the concept and the space-time relationship in destinations began to be investigated.

Despite the importance of the study of the tourist movement, there are no formally proposed methodologies, although there are several tools that allow both the capture of data and the process of analysis of the same. In fact, in Reference [3], they claim that, due to methodological inadequacies, many of the existing studies have limitations. In this sense, many works are focused only on the intra-destination mobility of tourists, leaving aside the study of mobility in combination with facts and experiences. Some are about the simulation of agents [4] and pedestrian analysis [5]. Some others analyze technological alternatives of tracking [6,7], reference [8] with their proposed micro and Macro alternative or References $[9,10]$ with their studies of movements from multiple sources.

Beyond the use of new technological tools to capture data, research in tourism requires methodologies to obtain and analyze data with a higher spatial and temporal resolution and to take into account that most of the tools currently used present severe problems of invasion of tourist's privacy. This also makes it necessary to consider alternative tools to obtain data on the tourist movements, avoiding such invasion.

In line with the above, the present study considers that the study and analysis of the concept of traceability can provide additional information and is useful for the traditional study of the movement of tourists. Traceability refers to the set of actions, measures and technical procedures that allow to identify and record each product from beginning to the end of the marketing chain [11]. Other authors [12] define it as the ability to follow (in real-time) or to rebuild (off-line) the path of an individual or compound product. Specifically, the inclusion of this concept may be interesting for the capture of data that allows knowing the movements of the tourists in a destination.

Therefore, the focus of this work lies in two aspects-the study of the main works on tourist movement and to apply methodologies of traceability. Although the literature has studied the movements of tourists from different perspectives such as consumer behavior, geography, sociology or technology extensively, resulting in a variety of technological tools which allow us to understand how tourists move in a destination [13], the existing literature does not contemplate the use of traceability methods. This research aims to broaden the knowledge about additional methods on the study of tourist mobility and to go beyond the already applied technological tools (GPS, NFC, RFID, APPS, among others). Thus, an in-depth review of the study of the mobility of tourists based on traceability methodologies will help to answer the following research question-can traceability methods be applied to the study of tourist mobility?

The results of the work reveal that the theme of movement analysis implies a valid scientific trend, but there is no research-oriented with the traceability approach. In this way, it can be affirmed that, in the first instance, it is possible to integrate the concepts "tourist movements" and "traceability" to contribute to the enhancement of the processes and tools that have so far been applied in the study of tourist movements. In this sense, the interest to introduce the concept of traceability in the study of tourist movements goes beyond the use of a specific tool for the capture of information. It focuses on a whole methodology that, with its characteristic elements, can contribute to the improvement of the methodological approaches used so far, also helping in the solution of problems related to the accuracy and validity of the data collected with the traditional tools and those existing so far. Finally, all those results contribute to a reliable understanding of the field as a promising element of tourist behavior.

\section{Literature Review}

The review of the literature presented below analyzes the two key concepts addressed in this paper- "tourist movement" and "traceability." The objective is to clarify both terms to carry out the science mapping analysis and to study their results. 


\subsection{Conceptualization of Tourist Movement}

Movement or mobility is a significant element in tourism research and especially in sustainable tourism research [14-18]. Movement represents a key aspect, since it is the one that allows us to travel from a place of origin to a chosen destination [5], and also to move within a destination. The first authors to report observations of tourists and their movements in defined environments using hidden observation and interview to trace the movements of the travelers who visited Salzburg (Austria) [19]. Other works such as Fennell [20] study the Shetland Islands, UK, through a methodology called "space-time budgets," which focused on how tourist groups use facilities, attractions, transport and accommodations in a particular area of study.

Other studies related to tourist movement have considered tourist travel patterns (patterns of movement and tourism styles in urban destinations) [21]. The topological characteristics of tourists behavior, in a group approach [22]; and, in a similar sense, Reference [23] explored urban transport and behavioral modeling of tourists to identify the explanatory factors that influence tourism movements.

From a marketing point of view, part of the importance of studying tourist movements is the knowledge of their behavior, which [22] contains diverse information that is useful for the development of marketing policies and services. On the other hand, the information obtained from these studies can be helpful in the elaboration of scenarios in terms of prediction of tourist visits and the effects of advertising, giving a possible idea of how a city will visit and the possible measurement of the effect of localized advertising [24].

Regarding sustainability, and sustainable development as part of it, it is relevant to understand the behavior of visitors in a particular tourist area since the spatial and temporal patterns of visitors affect the planning $[25,26]$ and management $[27,28]$ of destinations. They provide information on infrastructure needs, transport and new product development [29]. Even such studies would help to control the massification of destinations, considering when tourists perceive that a destination is crowded. Destination Managers (DMOs) should consider mobility studies as a strategic component when formulating comprehensive and effective public policies to guide destination planning on issues related to transport and sustainable tourism in general [30]. This means, as mentioned above, their satisfaction decreases and the sustainable development of the destination gets worse [31]. The work done so far has focused on studying the tourist movements between destinations, and their place of residence [32-36]. Others have analyzed particular cases, mainly parks or natural areas $[13,37-40]$.

From the transport point of view, the study of tourist movement is critical because of its possible influence on the planning of the same, to avoid congestion; and also to manage the destination's load capacity, as presented in Lew and Albrecht [41-46]. From the administration and management of a destination point of view, studies have focused mainly on the analysis of the behavior of tourists, based on information on the movement of flows [47,48]. Other works focus on information and help tourists in specific places such as natural parks, depending on the cases [49-54] or for decision-making regarding infrastructure congestion and overburden in natural areas [55-62]. The different perspectives from which the mobility of tourists has been studied give us more in-depth knowledge on the subject. However, even today, it is necessary to establish methodologies that support the decision-makers of the DMO in the management of their tourists' movements. Below are different approaches to traceability as a new prism for this type of studies.

\subsection{Conceptualization of Traceability}

The concept of traceability, as mentioned above, refers to the identification and registration of products along the entire marketing chain [11,63-66]. The traceability of products arose due to scandals and problems worldwide by the management of various types of food [67-71]. From these events, it has been necessary to advance food traceability systems to increase end-user confidence [72,73]. 
There are different approaches on types of traceability; some authors consider that the traceability can be horizontal or vertical-horizontal, to be able to trace some characteristics between models of a different class and vertical, to trace elements within the same model-this orientation is applicable within computer models [74]. Another approach considers chain traceability and internal traceability; the first is given along discrete steps of the logistic chain and the internal one within those steps [75].

For Kim, Fox and Gruninger [76], the center of traceability is termed the traceable resource unit and traceability is based on the relationship between them. To this concept, Moe [75] adds that the elements to be drawn up must have a unique identification. Subsequently, Storøy et al. [77] base their proposal on similar elements but add that it is relevant to identify and record the transformations of the items to be drawn. In Keller and Niuttgens [78] later taken up in Ziemann, Werth, Matheis, and Kahl [79], Kiepuszewski, ter Hofstede and Van der Aalst [80], Van der Aalst, ter Hofstede, and Weske [81] and Van der Aalst [82] propose to treat traceability based on the processing of events that contain elements such as functions, events and logical connectors between events.

\section{Traceability Analysis Methodologies and Tools}

The majority of traceability references are based on data processing schemes or management of enabling technologies; there are few existing references, from the point of view of the process as such, although they have elements in common. In relation to the methodologies, the following paragraphs analyze some references that may be of interest for this work:

- Business process reengineering of a supply chain and a traceability system: This methodology, proposed by Bevilacqua, Ciarapica, and Giacchetta [83] is particular for the traceability of plants and defines it as the process of analyzing the Logistic chain and network. This methodology suggests redefining the logistic chain in three large blocks: Labeling block, block of traceability applications and block of data accumulation.

- $\quad$ Best practices in traceability of the EAN Belgium: The EAN Belgium report [84], suggests six steps to implement a traceability system, ranging from preparation to internal audit and testing (which involves the own analyses of pilot implementation and their possible incorporation of a permanent way in the logistic chain).

- GS1 Global Business Language: GS1 is the organization that currently promotes and coordinates the processes for product labeling in logistics chains and traceability of food products, has proposed a general 10 step and three general stages model applicable to each logistics chain. It has developed specific implementations for the health sector [85], for the fruit chain [86], and for the Wine chain [87]. The suggested stages are preparation, planning and implementation or operation.

- BRIDGE project methodology: The BRIDGE project (Building Radio Frequency Identification for the Global Environment) [88] was a project funded by the European Commission under the Sixth FP6 Framework Program between 2006 and 2009 [89]. The objective was research, Implementation, and development of solutions based on EPCGlobal, for several logistics chains in Europe. This project proposes a methodology for the implementation of traceability systems focused on EPC (Electronic Product Code).

- Framework for choosing an auto-ID technique in the supply chain. Ilie-Zudora et al. [90], based on a systemic review of multiple references, propose six steps, within two levels on which to address the problem of specifying, developing and integrating identification solutions for traceability purposes. The defined levels are a strategic level and a technical level. At the strategic level, decisions are analyzed at the level of requirements on what is needed and can be implemented later at the technical level.

- Link-All project [91,92], funded by the European Commission under the @lis program of cooperation between Europe and Latin America between 2003 and 2006 and developed among 17 partners from Latin America and Europe. Its objective was to provide and assist five pilot companies in the sectors of handicrafts, ecotourism, and culture, in 5 Latin American 
countries with innovative technological tools. This project developed several tools for the internet and mobile devices, and a methodology for traceability applicable to small logistics chains, emphasizing in the crafts [93]. This methodology defines some areas of the organization that are impacted by traceability processes such as infrastructure, software applications, processes, and human talent. Subsequently, it describes four states in which organizations can be found, concerning the adoption of essential traceability systems but not only in RFID (Radio Frequency Identification). These levels are apprenticeship, experimentation, evaluation, and adoption

In order to develop a traceability system, it is necessary to determine the identification systems, which are used to manage information relating to persons and objects, for which magnetic, optical, sound and printed forms are used. Among the possible enabling technologies we find electronic vision, bar codes, and RFID. Generally, these systems require two fundamental components-a codified element containing the information (processed data following some pre-established standard or pattern) and an element capable of recognizing the information; for example, to use a GPS as a data capture tool, a GIS (Geographic Information System) is required to process the collected data. Thereafter, the reader equipment communicates with a processing unit such as a computer, or to a mobile device connected to a data network, where various processes are performed. Initially, the data are decoded, that is, they become information understandable for the machines, then access to services that interpret the information and use of specific processing services as the case. For this, there are currently standards and technologies which are described throughout this section.

The EAN-UCC, currently EPCGlobal [94] is the leading global organization in the supply and demand chain, the EAN-UCC standard from which it comes, has been established as the best practice for traceability [95], and which is a virtually unique and international standard for product identification and the exchange of information of member organizations. Belonging has the advantages of performing traceability with standards, it is the support of a third party, in ensuring compatibility between the different partners in the logistics chain [96]. Among the best-known technologies are bar code; Radio frequency identification (RFID) technologies (use EPC and the variation known as NFC [97-99], designed for the identification of objects that have labels that can be read by mobile phones); Global Positioning Technologies-GPS and Internet of Things [100,101].

From the review of the literature, it can be inferred that there is no single traceability system but that it depends on the element to follow, the regulatory aspects that must be met according to the country, region or type of product. Among the elements common to all referents are unique identification, the administration of links or relationships between the units to be identified, the recording of information and communication of the same.

Methodologically, none of the studies carried out to date use the term traceability for the study of tourist movements. Although tracking and tracking tools are used, they present different problems and disadvantages, which require attention for future research in tourism. In this way, the study of both concepts can contribute to a better knowledge of the methodological approaches used in the studies carried out in both fields, also help in the solution of problems related to the accuracy and validity of the data collected with the traditional tools and those existing so far. It is important to bear in mind that, beyond the greater knowledge about tools for capturing information from tourist movements, which may be similar or even used in other traceability studies, the study of both concepts may give rise to a new methodology applicable to the study of tourist movements.

\section{Materials and Methods}

The present research takes a quantitative approach, based first on descriptive statistics from the mainly bibliometric sources and further science mapping analysis. Borgman and Furner [102], Grivel, Polanco, and Kaplan [103], Santhanakarthikeyan, Padma, Veeramani, and Ravikrishnan [104] agree that bibliometrics and science mapping are a set of methods for quantitatively analyzing scientific literature. Among the works that use bibliometrics and science mapping are those of Garfield [105], who proposes a bibliographic system for the study of articles, based on its relevance and citation index. 
In addition, we defined the coupling between cited articles, which would then be known as co-citation, which was previously worked by Small and Greenlee [106] and Marshakova [107].

Thus, science mapping allows us to describe, evaluate and follow research in a given field, allowing us to analyze the impact of a particular subject, a set of researchers or a particular document [104]. In the present work, the science mapping method will be used in order to explore the research carried out on the movement of tourists and traceability. To present the information collected in a structured way when applying the different science mapping methods in a scientific investigation, it is important to use graphical representations of the connections that may exist. It becomes one of the elements that concretizes and demonstrates the usefulness of this evolution of bibliometrics field [108-112].

The most relevant software tools for this analysis and mapping we found are Bibexcel by Persson [113], Citespace II by Chen [114], CitNetExplorer de Eck and Waltman [115], Leydesdorffs Software [116], Matheo Analyzer [117], Sci2 Tool [118], SciMat [119], ScientoPy [120] or VOSViewer [110]. Between all these tools, we found the most used is Citespace with some cases applied to tourism research as in References [121-124]. This software facilitates the analysis of trends in scientific research based on the analysis of bibliographic references. It allows the detection, analysis and visualization of different patterns of their behavior, which can be represented by graphs and networks that can be constructed from bibliometric data such as authors, co-authors, institutions, countries, keywords, citations, among others; this visualization can be given in the form of clusters or timelines.

The importance of using this type of science mapping tools lies in covering the need to handle a wide range of bibliographical references, given their breadth and heterogeneity; that is, the volume of data on a subject, area or scientific discipline is such that, today, for its management, higher processing capacity is required; the relations between them are not evident, under the primary literature analyzes that the documentary investigations carried out until recently. Also, science mapping is a fundamental tool for clarifying trends that are necessary to highlight the significance and relevance of a research topic.

In order to fulfill the main objective of this work, it is important to define the steps that involve all the activities necessary for such an analysis and to know the degree of innovation and contribution to knowledge. In this way, we propose a scheme based on the science mapping revision, starting from the selection of search criteria and sources of information, through the search of statistics of the selected sources and ending with the analysis of relevance.

\subsection{Selection of Search Criteria}

The selection of terms for the search in the sources of information, although it is extensive, has the advantage of covering publications in tourist and non-tourist journals [125], which assures a higher number of results that will have to be refined, deciding which contribute to the subject of research. Taking into account the above, and considering that the purpose of this research is the study of tourist movements and traceability, the selected key terms are related to three essential thematic axes: traceability, movement, and tourism. To address these terms in the conduct of the search, we must consider adjustments to them, to obtain the expected results.

For the term "traceability," where no synonym is directly associated, equivalent terms such as "tracing" or "tracking" will be selected; for the term "tourism", terms associated with it will be considered as "touristic" and "tourist." Finally, for the term "movement," there are synonyms such as "flow" and "circulation," which according to tourist theory are closer to economic studies, which are far from the central topic of the present investigation and such a reason is decided to leave the initial term. Based on the above terms and in order to focus the search on the main research topic, it is decided to make combinations of the terms, and assign them a code (letters " $a$ " to " $\mathrm{h}$ "), to facilitate the presentation and writing of the analysis of the results, defining the following listing, in Table 1 of terms and combinations: 
Table 1. Search criteria based on terms combination for search.

\begin{tabular}{cc}
\hline Codification & Term Combination \\
\hline $\mathrm{a}$ & Tourist + Traceability \\
$\mathrm{b}$ & Tourist + Movement \\
$\mathrm{c}$ & Traceability + Movement \\
$\mathrm{d}$ & Tourist + Trace \\
\hline
\end{tabular}

\subsection{Selection of Information Sources and Search}

The literature review begins with a systematic survey of sources of on-line scientific information, including journals and conference databases. We explored the most extensive databases of scientific knowledge, such as Clarivate Web of Science and Scopus. We perform the search beginning the second half of the year 2019 data for this year is considered partial. For the two databases, the search was performed for all available years and only journal papers and conference proceedings, forming a dataset of references.

The search for statistics in the sources of information mentioned in the previous section is done taking into account the list of terms established in Table 1. For a better presentation and management of the information, Table 2 shows the results found for the combination of words with the code assigned for their identification:

Table 2. Search results for term combination.

\begin{tabular}{lccccc}
\hline Source & $\mathbf{a}$ & $\mathbf{b}$ & $\mathbf{c}$ & $\mathbf{d}$ & TOTAL \\
\hline WOS & 10 & 1.249 & 278 & 538 & 2.075 \\
SCOPUS & 5 & 986 & 224 & 366 & 1.581 \\
TOTAL & 15 & 2.235 & 502 & 904 & 3.656 \\
\hline
\end{tabular}

\section{Results}

The results of the search show that altogether 3.656 records were found in these two main databases. The combination of words with the highest number of records was "[c]: tourist movement" with a total of 2.235 , followed by "[b] tourist trace." Given the high number of publications found, applying the search by combinations of criteria, the relevant relevance analysis was performed by researchers.

\subsection{Relevance Analysis}

The relevance analysis consists of reviewing in detail the publications found and analyze if they are related to the central theme of the research and if they are relevant. Table 3 presents the results of relevant records, according to the search under the sources and criteria, previously defined. At the search criteria level, the criterion with the greatest results is "[c] tourist movement."

Table 3. Relevant references in searches of related terms.

\begin{tabular}{lccccc}
\hline Source & $\mathbf{a}$ & $\mathbf{b}$ & $\mathbf{c}$ & $\mathbf{d}$ & TOTAL \\
\hline WOS & 1 & 116 & 0 & 17 & 134 \\
SCOPUS & 1 & 137 & 0 & 21 & 159 \\
TOTAL & 2 & 253 & 0 & 38 & 293 \\
\hline
\end{tabular}

According to the results presented in the table above, Table 4 is designed, which relates the relevant articles for each of the search criteria, without considering those that have previously been related to other sources. Therefore the table only relates the relevant additional articles that were found. The results with zero are also omitted. 
Table 4. Relevant references in searches of related terms.

\begin{tabular}{llll}
\hline Source & Search Criteria & Relevant Papers & References \\
\hline \multirow{2}{*}{ WOS } & {$[$ a] tourist traceability } & 1 & {$[126]$.} \\
& {$[\mathrm{b}$ tourist movement } & 117 & {$[3,6,13,21,23,29,53,54,61,127-234]$.} \\
& {$[\mathrm{d}]$ tourist trace } & 17 & {$[2,19,235-249]$} \\
\hline \multirow{2}{*}{ SCOPUS } & {$[$ a] tourist traceability } & 1 & {$[250]$.} \\
& {$[\mathrm{b}]$ tourist movement } & 22 & {$[24,47,251-270]$.} \\
& {$[\mathrm{d}]$ tourist trace } & 3 & {$[271-273]$.} \\
\hline
\end{tabular}

\subsection{Citation Volume}

In first of the results that are shown next is the publication volume trend from 1981 to 2019. Considering the information on the date of publication of the selected articles, the publication volume trend of the selected works is observed; that is, the articles that were relevant to the investigation. Figure 1 shows that "tourist movement" and its variants, at least within the sample selected as relevant, began to appear in the research agenda in 2005, and with a relative sustained growth since 2010, positioning itself as an up to date important topic.

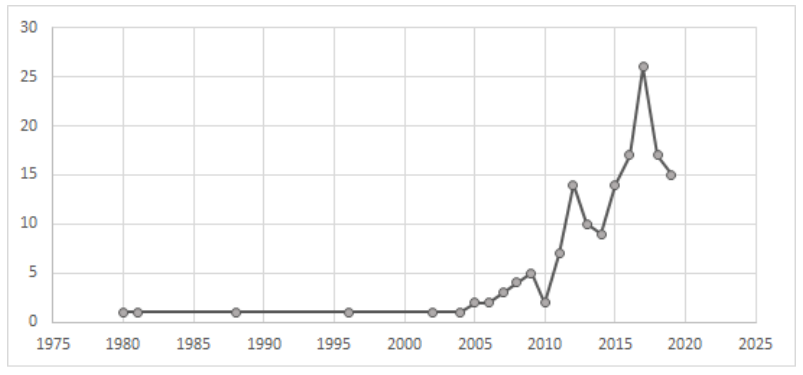

Figure 1. Publications per year.

The analysis of citations consists of reviewing how many citations each of the articles that have been selected as relevant, you can observe the trend in the publication and global citation around the subject. For this analysis, the citations are used that are in the database of WOS and in Google Academic, from which the following can be deduced: The number citations in Google Academic is higher than in the WOS database because it collects various additional sources that do not include WOS. Citations in WOS correspond only to articles classified in their own database. The trend in the top 10.

Finally, taking the 10 most cited articles in the two databases, which present a similar behavior in their citation, are:

- Modeling tourist movements-A local destination analysis in A. Lew and McKercher [23], related to a proposal of how tourists move by proposing patterns.

- Digital Foot printing: Uncovering Tourists with User-Generated Content in Girardin et al. in Reference [166], related to a proposal of analysis of movements of tourists based on the multimedia information and web activity that they generated.

- Movement patterns of tourists within a destination. Mckercher and Lau in Reference [21], identified 78 discrete movement patterns in urban destination.

- Seasonal tourism spaces in Estonia: Case study with mobile positioning data. Ahas et al. in Reference [131] showed the mobile positioning data is used to know the activities carried out by foreign tourists in Estonia, which allows them to decipher their space-time movement

- Exploring the travel behaviors of inbound tourists to Hong Kong using geotagged photos. $\mathrm{Vu}$ et al. in Reference [273] present a study using geotagged photos in Hong Kong.

- Tracking technologies and urban analysis. Shoval in Reference [6] presents a proposal aggregating data from GPS receivers in the Old City of Akko (Israel). 
- Mining Travel Patterns from Geotagged Photos. Zheng et al. in Reference [149] investigate spatiotemporal movements based in photos with tags.

- GPS as a Method for Assessing Spatial and Temporal Use Distributions of Nature-Based Tourists. Hallo et al. [150] presents a study about GPS offers advantages over other methods.

- Understanding tourists' spatial behaviour: GPS tracking as an aid to sustainable destination management. Edwards and Griffin in Reference [139] presents a study with 154 participants using GPS to construct and analyse maps.

- Time and Space in Event Behavior: Tracking Visitors by GPS. Pettersson and Zillinger in Reference [3] present a study using GPS in the Biathlon World Championships 2008 in contrast to other traditional technologies.

\subsection{Most Cited References}

For this analysis, we use the Citespace tool [274], used for the visualization and analysis of trends in scientific literature, created by the information visualization expert Chaomei Chen of the University of Dextrel. This tool is selected among others, given its gratuitous nature and the scientific support of it. To make use of this tool, a Citespaceproject was created to perform a data preparation, which includes the following activities:

1. Collection in WOS of the bibliographic formats (ISI flat format) of each of the articles selected as relevant.

2. Since WOS only contains a fraction of them, use is made of the tool PoP Publish or Perish [275], which delivers information from Google Scholar.

3. For items that are not in WOS, all fields corresponding to the number of times an item has been quoted (TC field of files) are manually updated to obtain a standardized set of references that will be analyzed by the tool.

In a first analysis of cited references, using a time scale between 1980 and 2019 (more complete subset of references) with cuts every year and considering the twenty articles most cited by each cut, Figure 2 is generated, which shows the network of references most cited within the selected articles, under a co-citation analysis of references and grouped in clusters according to a common topic. A cluster represents a grouping of similar elements in nature and type of analysis, but with different characteristics when compared to other clusters.

According to the first two figures, corresponding to the network of co-citations of the most cited references and the extraction of terms from the summary of clustered articles, a Sigma analysis is performed. The Sigma analysis is based on an indicator of the tool, which has been conceived as a measure of novelty within the reference space and which results, in the same order, in the articles most cited by other authors and therefore, are relevant to the current research or are part of the conceptual basis. They are:

- $\quad$ First and Repeat Visitor Behaviour: GPS Tracking and GIS Analysis in Hong Kong. See in figure node with label MCKERCHER B, 2012 [276].

- A Social Network Analysis of Overseas Tourist Movement Patterns in Beijing: the Impact of the Olympic Games. See in figure node with label LEUNG XY, 2012 [143].

- Movement Patterns of Tourists within a Destination. See in figure node with label MCKERCHER B, 2008 [21].

- Understanding tourists' spatial behaviour: GPS tracking as an aid to sustainable destination management. See in figure node with label EDWARDS D, 2013 [139].

- Modelling spatio-temporal movement of tourists using finite Markov chains. See in figure node with label XIA JH, 2009 [164].

- Tracking technologies and urban analysis. See in figure node with label SHOVAL N, 2008 [6].

- Exploring the travel behaviors of inbound tourists to Hong Kong using geotagged photos. See in figure node with label VU HQ, 2015 [273]. 
- Modeling Tourist Movements: A Local Destination Analysis. See in figure node with label LEW A, 2006 [23].

- An analysis of visitor movement patterns using travel networks in a large marine park, north-western Australia. See in figure node with label SMALLWOOD CB, 2012 [13].

- Intra-attraction Tourist Spatial-Temporal Behaviour Patterns. See in figure node with label HUANG XT, 2012 [147].

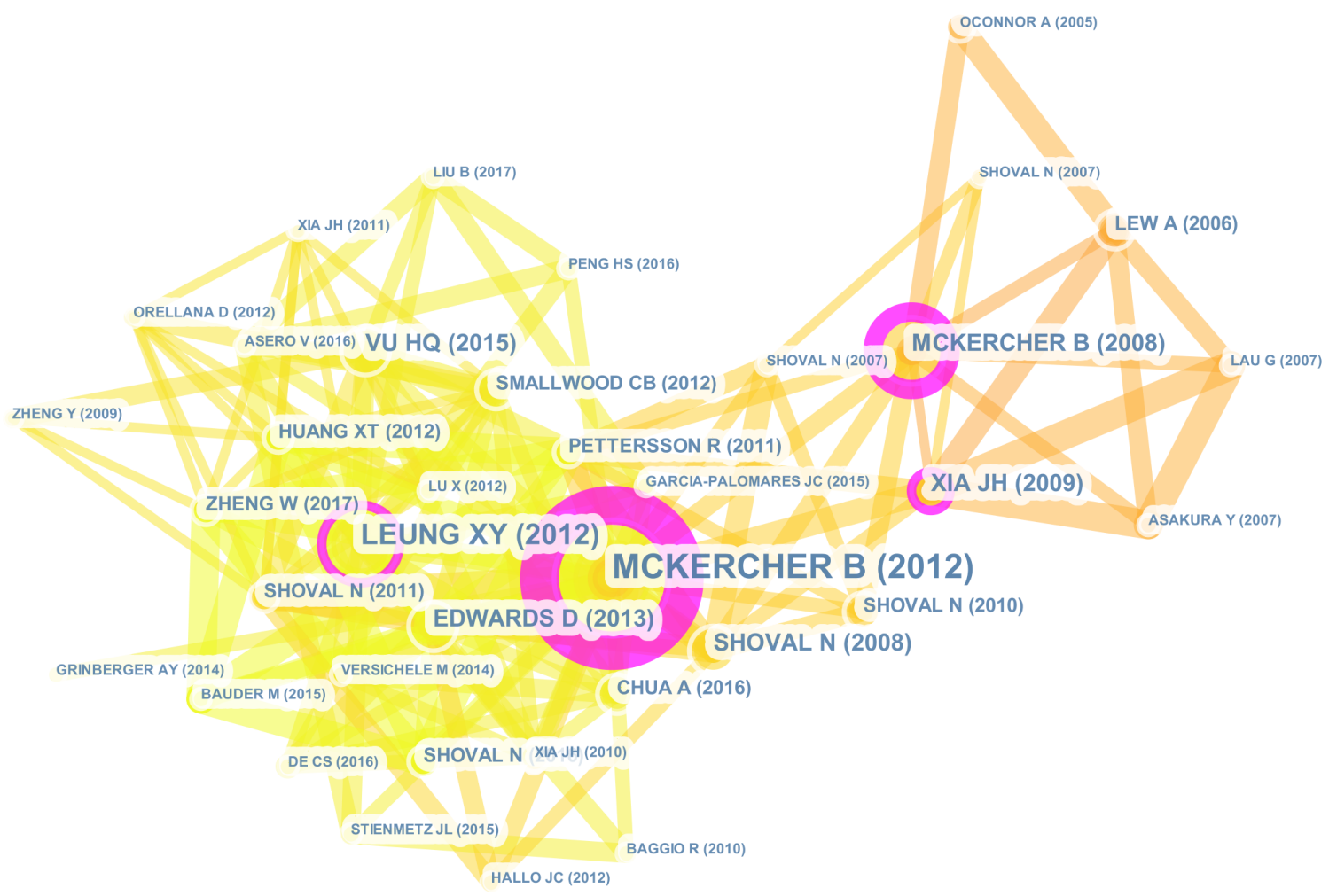

Figure 2. References co-citation network.

Using Citespace, we generate the Table 5 for the conceptual analysis based on clusters and extracting a sequence of terms from the abstracts and keywords from the references. This is based on three analysis models analyzing the terms (concepts) from each reference:

1. Latent semantic indexing (LSI) that uses a mathematical technique to identify patterns in the relationships between the terms.

2. Log-likelihood ratio or LLR1 based on the analysis of most common term or concept from the references.

3. Mutual Information or MI based on the analysis of mutual dependence for terms as variables of concepts generated from the references.

Table 5 indicates the terms groups in 11 clusters more relevant based on each model. The ID is for clarification purpose from 0 to 10 . The second column indicates the number of references in each cluster and the third one presents the mean year of publication for each group. The blank spaces mean that the model cannot process successful analysis for each cluster but all the clusters have at least one successful processing. 
Table 5. Clusters generated based on three model of analysis.

\begin{tabular}{|c|c|c|c|c|c|}
\hline ID & Size & Year & LSI & LLR & MI \\
\hline 0 & 12 & 2014 & $\begin{array}{l}\text { graph theory; areas; } \\
\text { mountain; combining } \\
\text { gps tracking }\end{array}$ & $\begin{array}{l}\text { backcountry skier; graph } \\
\text { theory; combining gps } \\
\text { tracking }\end{array}$ & $\begin{array}{l}\text { anomalous urban mobility } \\
\text { pattern; semantic trajectories; } \\
\text { using genetic algorithm }\end{array}$ \\
\hline 1 & 11 & 2015 & $\begin{array}{l}\text { huashan; smart scenic } \\
\text { area management; travel } \\
\text { blogs; }\end{array}$ & $\begin{array}{l}\text { tourism } \quad \text { statistics; } \\
\text { empirical } \quad \text { evidence; } \\
\text { multi-destination trip }\end{array}$ & $\begin{array}{l}\text { using genetic algorithm; } \\
\text { unvisited tourist place; } \\
\text { anomalous urban mobility } \\
\text { pattern }\end{array}$ \\
\hline 2 & 10 & 2015 & $\begin{array}{l}\text { analysis; huashan; smart } \\
\text { scenic area management }\end{array}$ & $\begin{array}{l}\text { using travel network; } \\
\text { large marine park; visitor } \\
\text { movement pattern }\end{array}$ & $\begin{array}{l}\text { intra-destination } \\
\text { transport mode; bivariate } \\
\text { probit model }\end{array}$ \\
\hline 3 & 5 & 2014 & $\begin{array}{l}\text { tourist sites; hiking; } \\
\text { roads }\end{array}$ & $\begin{array}{lr}\text { overseas } & \text { tourist } \\
\text { movement } & \text { pattern; } \\
\text { social network analysis; } \\
\text { olympic game }\end{array}$ & $\begin{array}{l}\text { using genetic algorithm; } \\
\text { anomalous urban mobility } \\
\text { pattern; semantic trajectories }\end{array}$ \\
\hline 5 & 3 & 2017 & $\begin{array}{l}\text { tourist flows; southern } \\
\text { Italy; social media data }\end{array}$ & $\begin{array}{l}\text { tourist flow; southern } \\
\text { Italy; mapping cilento }\end{array}$ & $\begin{array}{l}\text { mobility; place; enchantment; } \\
\text { using genetic algorithm }\end{array}$ \\
\hline
\end{tabular}

Once the clusters are identified and the terms are extracted from the abstracts and keywords from the references, we selected the Tf-idf model and process in a visualization network as presented in Figure 3. The cluster with more size (cluster \#0) is "Spatial behavior", follow by cluster \#1 related to "Field Research" and the cluster \#2 with the name "geo-temporal tracking." The others cluster are about specific cases, urban patterns, digital era topic.

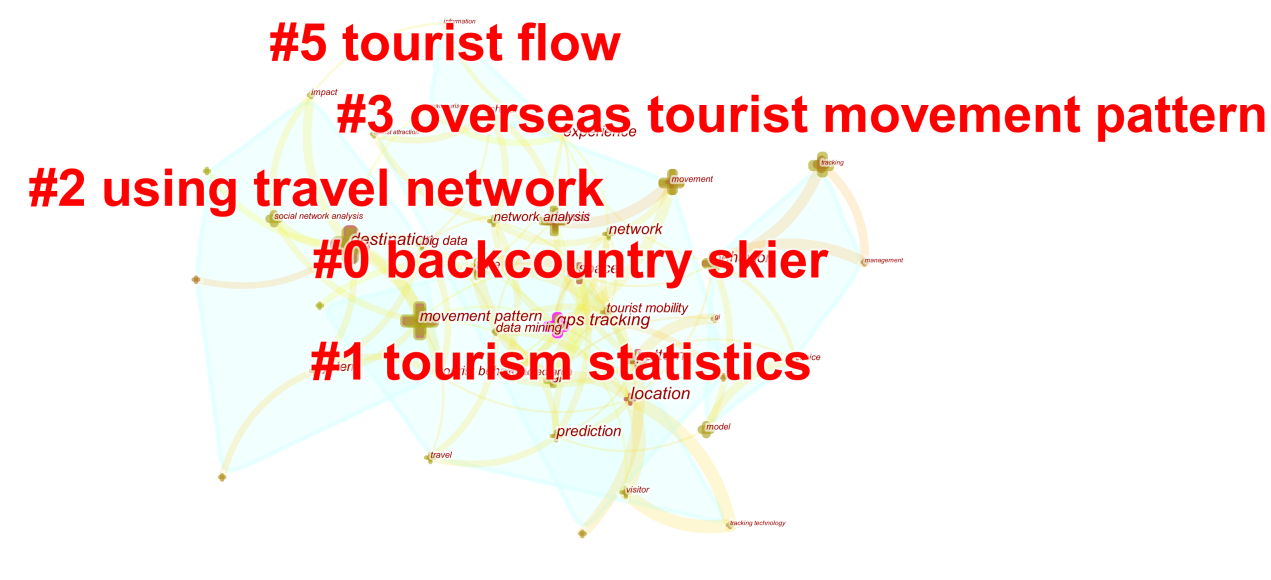

Figure 3. Visualization of clusters generated using Tf-idf model.

\subsection{Co-Citation Networks}

Additional to previous analysis, we perform a co-citation analysis presented in Figure 4. The relations between authors means the most frequent co-citation presented. These authors with their main publications are Mckercher [21,43,167,252,277], Shoval [5,6,154,278], Lew AA [23,41], Lau G [8], Xia [155,159,161,163,164,168]; Edwards D [139,279]; Leung XY [143]; Fennell [20]; Vu HQ [273], Ahas R [131,280,281] , Hallo [150]; Oppermann [34]; Leiper N [282]; Dietvorst A.G.J [283] and Asakura Y [22]. 


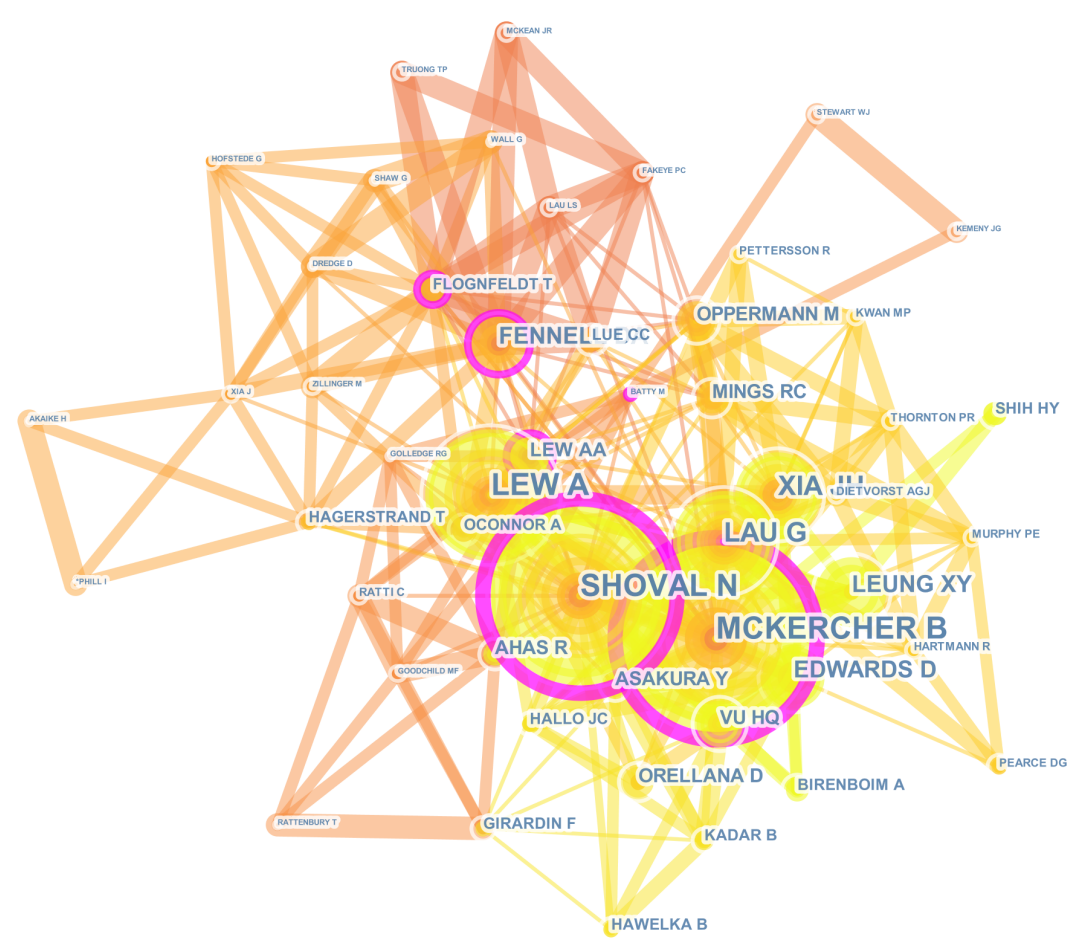

Figure 4. Author co-citation network.

Following the network co-citation analysis, another relevant element is the citation of journal inside the selected references. Figure 5 shows the Journal co-citation network. In this figure we can find the nodes with more size are "Annals of Tourism Research," follow by "Tourism Management," "Tourism Geographies," "Journal of Travel Research," "Lecture Notes in Computer Science" and "Math computer simulation." It is relevant to highlight that most of these are classified mainly as journals in particular topics of tourism but technological journals are gaining space.

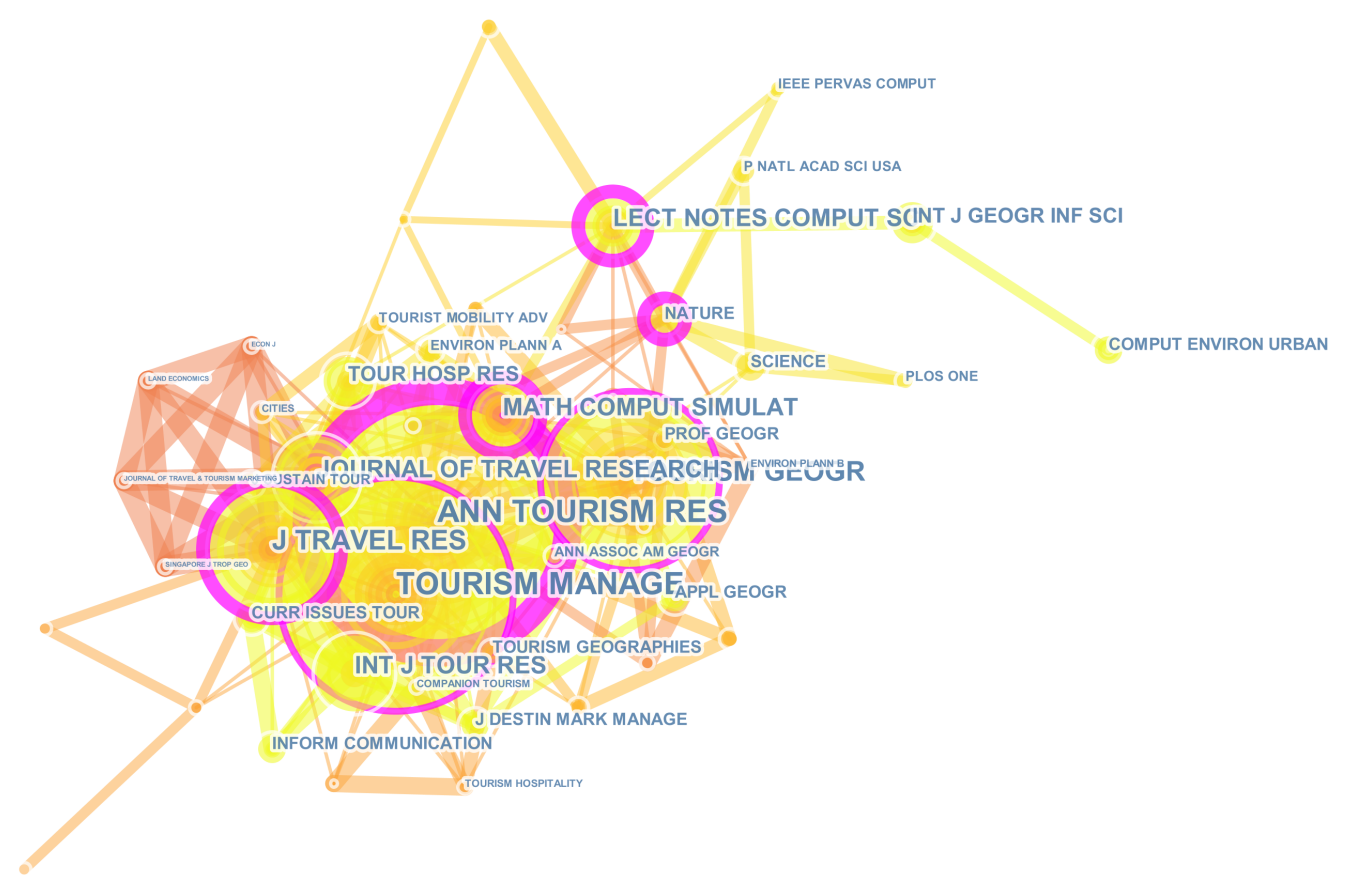

Figure 5. Journal co-citation network. 
The last main analysis is based on keywords. In this point, we process the keyword proposed by authors inside the references. Figure 6 shows the keyword network. We can find the nodes with more size are "movement pattern," "destination," "tourist," "movement," "pattern," "behavior," "time," "space," "GPS tracking," and "network analysis." These terms are present in the same part of the network. The purple ring presented in some nodes means a significant turning point linking the analysis performed and may have had significant influences on the development of the field in future.

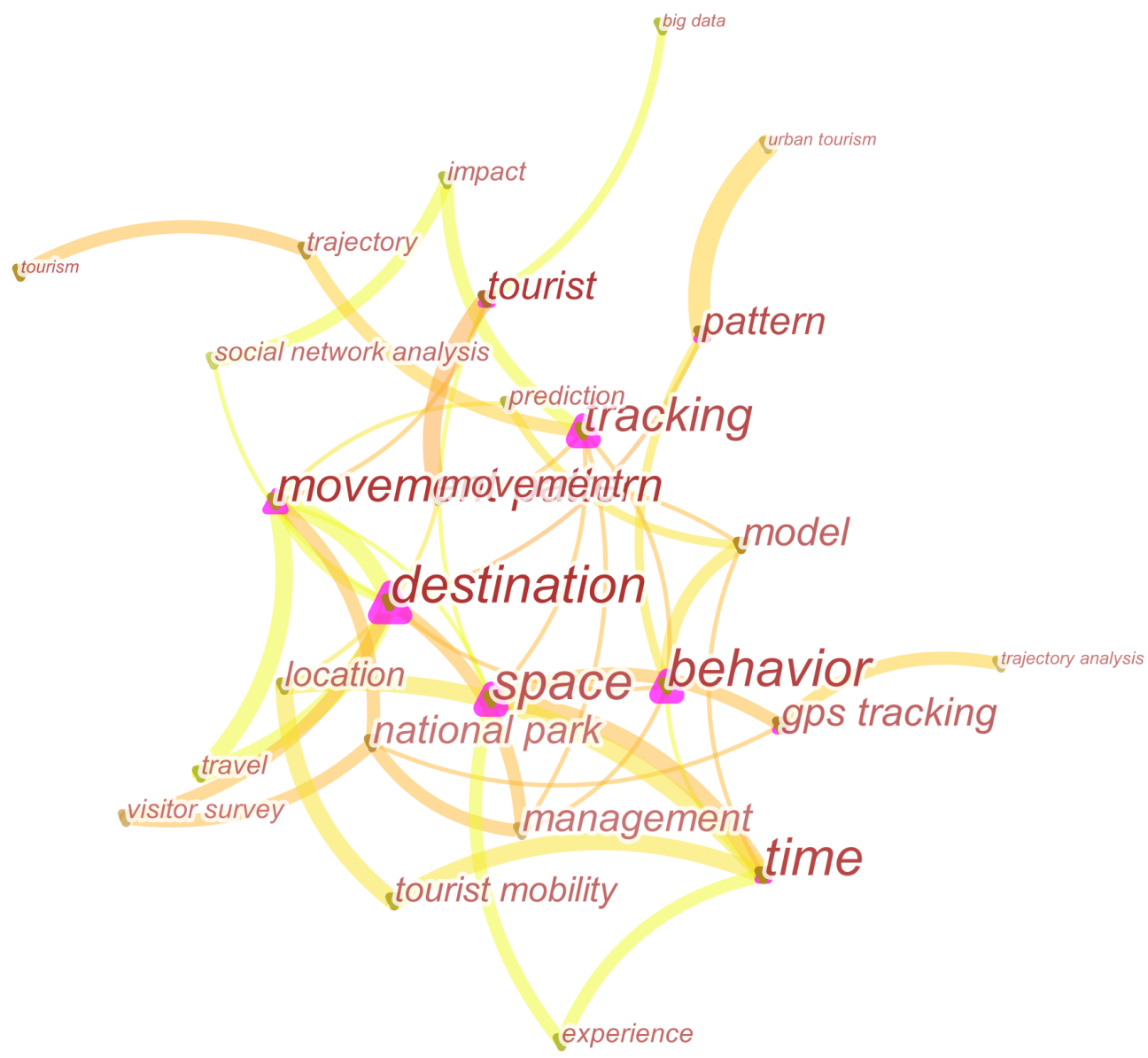

Figure 6. Keyword network.

\section{Discussion}

The different research experience on tourism requires quantitative data in order to control tourist flows and to analyze trends and perspectives. Although the boom in international tourism has undoubtedly generated many benefits, this growth has also begun to cause problems-the large number of visitors attracted by the main sights of tourist destinations has begun to be a concern for the representatives of the DMO (Destination Management Organizations) [284] . The representatives of the DMO must understand not only the movement of tourists in the destination but also the use of the space and tourism resources needed in order to be more sustainable [285]. Specifically, for the study of tourist behavior and therefore, their movement in space and time, there are no formally proposed methodologies but there are several tools that allow both data capture and the analysis of them. Different methodological considerations have been identified in Figure 7. These considerations are classified into 2 groups, according to the moment of the information capture. In the first group, 
those cases whose data were taken at the same time of the visit to the destination; in the second group, those cases where the data were collected after the visit to the destination or to the attractions.

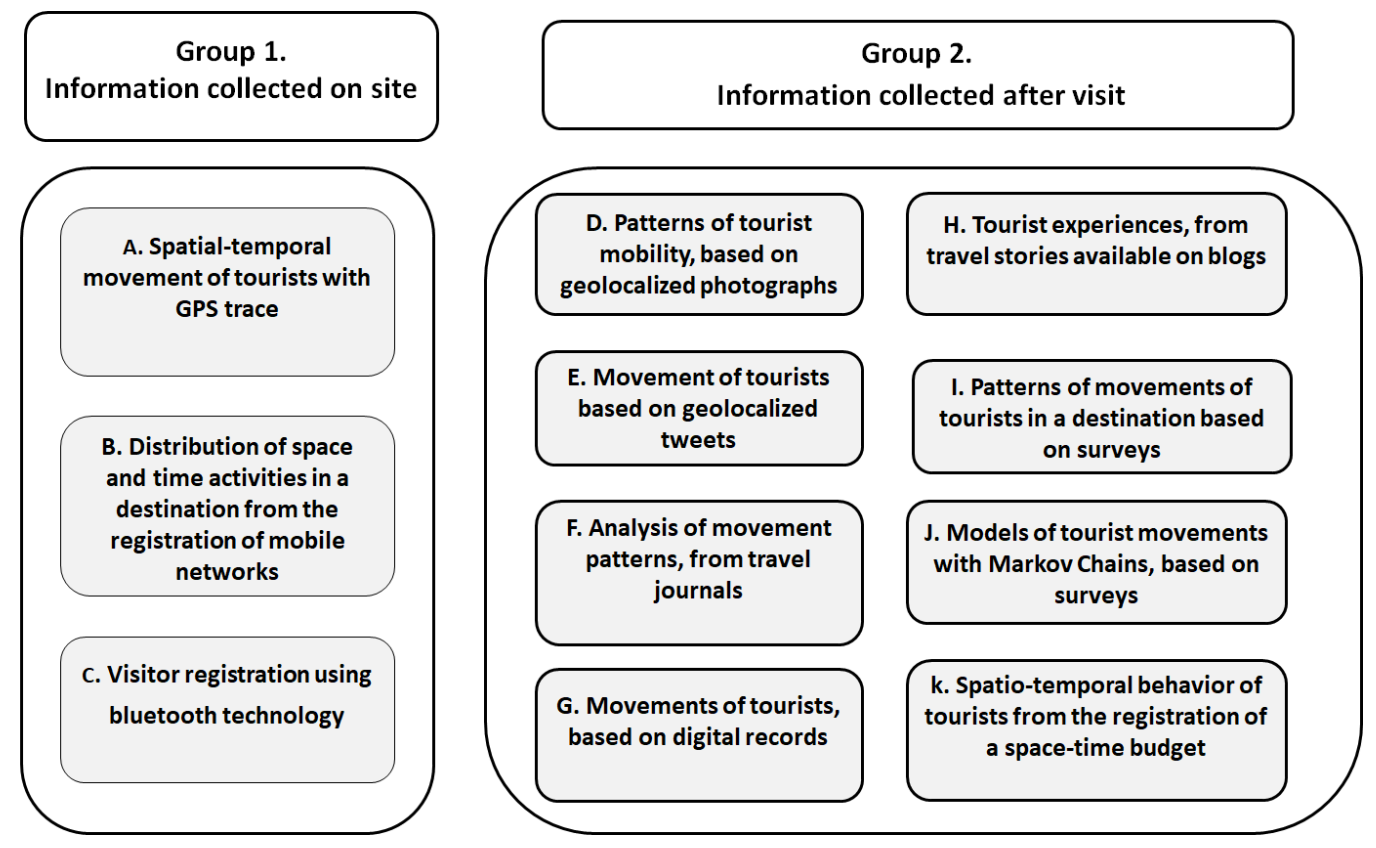

Figure 7. Methodological considerations.

In group 1 the option A about "the spatial-temporal movement of tourist with GPS trace" is widely developed in References [131,176,186,199,204,211,214,232,280,281,286-288]. In these proposals, the mobile positioning data is used to know the activities carried out by tourists, which allows them to decipher their space-time movement. This methodological consideration has a considerable limitation related to invisible tourists, and this means the tourist turns on the telephone but does not use it. Therefore, there are no records of their activity in the destination. Equally, it has a disadvantage, the concern for the surveillance and the privacy of the user and problems can arise for the access to the data, due to the professional secrets of the operators of the mobile telephony, which lead them to hide figures. Finally, as an advantage, it can be mentioned that the data is especially more accurate than questionnaires or accommodation statistics. This is the most wide type of study in last five years.

In option B, the "distribution of space and time activities in destination from the registration of mobile networks" is widely developed in References [165,225]. In those proposals are presented an evolutionary approach for urban studies and a new method of urban monitoring called mobile landscape. This is based on the location of data from mobile phones through GIS tools to study activity in urban space and time. This allows evaluating the number of people moving in the city. This methodological consideration presents as the main disadvantage, the invasion of the privacy of the tourist, also, there may be problems with access to the data due to the privacy of the operators of the mobile telephony. Finally, as an advantage, it can be mentioned that the data is especially more accurate than questionnaires or accommodation statistics.

In option C "visitors registration using Bluetooth technology" is widely developed in References $[289,290]$. In this proposal, authors try to demonstrate the potential of Bluetooth technology for the registration of visitors in tourist attractions. It made use of this technology incorporated into the mobile phones of tourists. This methodological consideration has its main disadvantage, the non-distinction between tourists and residents of the destination, which can lead to a bias in the information provided by the tool. It has the advantage of being anonymous since no personal data of tourists is record. Therefore researcher can get more collaboration from them. 
In group 2, when the information is collected after the visit, the option D "Patterns of tourist mobility, based on geolocalized photographs" is mainly developed in References $[128,149,157,230,240,243,266]$. These studies are based on the database of tagged photographs available on social networks. They are used to describe tourist mobility patterns using location data recorded in each photograph of the different tourist sites of a destination. The methodological consideration has as its primary advantage that it does not invade the privacy of tourists because the photos are published by their own decision. This means that it does not generate high collection costs because it takes data published on the internet and facilitates the analysis of multiple tourist destinations. Despite its benefits, some drawbacks are observed in this study. The sample only includes the travelers who decide to publish on the internet the photograph of their trips. These travelers have different national and social characteristics that are not easy to classify their publications on the web, which hinders the realization of a tourist profile. Finally, the published photographs are correlated with the aesthetics of the place. This means that they stop publishing other photographs that can give more information about the destination.

In option E about "movement of tourist based in geolocalized tweets" is mainly developed in References [134,230,244]. It is based on taking information from a collection of geolocated tweets from a specific area and reconstructing the movement of users. This is made through the trajectory of the traveler through several locations. It is necessary to obtain an overview of the movement of the users by obtaining temporal or semantic information. This methodological consideration has as main advantages, the non-invasion of the privacy of the travelers and the low cost of the acquisition of the data that is published on the internet. Despite its benefits, there may be a bias in the sample, since it is limited only to consider those tourists who explicitly mention the sites visited in a destination.

In option F "analysis of movement pattern from travel journals" is mainly developed in References $[147,167,194,291]$. The GIS software is used to analyze the information contained in travel journals supplied to tourists. Authors propose to extract the patterns of movement according to the declaration of the visit to one or several destinations. This methodological consideration has as its main advantage that it does not invade the privacy of tourists because it has the voluntary collaboration of visitors. The travel diaries contain real information about the visits made. On the contrary, given the great effort required by a traveler to fill with the details of each activity. Few tourists are willing to participate in this type of studies, being also a disadvantage that, there is considerable fluctuation in the quality of information due to possible memory failures when recording the details of the visit.

In option G "Movement of tourist based on digital records" is mainly developed in References $[166,198,241]$. In this alternative, the concept of the fingerprint is used as the trace of such a person, before, during and after his visit to a city. Before the visit, these traces happen when the tourist visits digital maps or travel websites about a particular destination. During the visit to the destination, the fingerprint is stored when accessing wireless networks when using mobile phones. After the visit, tourists publish photographs on the internet and add comments about them. All this information is used to know the presence and movement of tourists in a destination. The combination of tools and the accuracy are the principal advantage. On the contrary, it has several disadvantages. The main one is the invasion of privacy. It is difficult to realize a profile of the tourist since travelers have different nationalities and social characteristics, which are not identifiable with the digital records that they leave in the visit to the destination.

In option $\mathrm{H}$ "tourist experience from travel stories available on blogs" is mainly developed in References $[198,259]$. In this study, the authors used the concept of Netnography to analyze the stories of tourists visiting a destination and thus build movements. Some advantages are that it is found to be simpler and less expensive than traditional ethnography. The activities of the traveler are not affected by observation. Finally, its main disadvantage is related to the non-representative sample, since not all tourists visiting a destination publish their experiences on the web.

In option I "patterns of movement of tourist in a destination based on surveys" is mainly developed in References [13,262]. In these studies, surveys are applied during specific periods to 
visitors. With this information, movement patterns are identified. The application of the survey can provide a better level of detail than other methods. The disadvantages are in the difficulty of being able to interview tourists. Another problem is the quality and quantity of the information collected.

In option J "models of tourist movements with Markov chain based on surveys" is mainly developed in References [164,231]. This is a way of modeling the space-time movement of tourists at the macro level. This makes use of the analysis of Markov chains. In this study, the authors demonstrate how to calculate the probabilities of visiting a destination. As an advantage of this proposal, it uses surveys as its information collection tool. It also presents the advantages and disadvantages of option I.

In option K "spatio-temporal behavior of tourist from the registration of a space-time budget" is mainly developed in References [20,249]. This proposal focuses on how tourists use facilities, attractions, transportation and accommodations in specific access areas. A survey is conducted based on the place visited, the time of the visit and the time spent. One of the main problems is the quantity and quality of the information collected, which depends on the capacity of the interviewees.

Table 6 presents a summary of advantages and disadvantages of the analyzed methodologies.

Table 6. Summary of advantages and disadvantages of the analyzed methodologies.

\begin{tabular}{|c|c|c|}
\hline Methodologies & Advantages & Disadvantages \\
\hline $\begin{array}{l}\text { A. The spatial-temporal movement } \\
\text { of tourist with GPS trace }\end{array}$ & $\begin{array}{l}\text { Decipher space-time } \\
\text { movement } \\
\text { More accurate data }\end{array}$ & $\begin{array}{l}\text { Invisible tourists (turns on GPS but } \\
\text { does not use it) } \\
\text { No access to user profile }\end{array}$ \\
\hline $\begin{array}{l}\text { B. Distribution of space and time } \\
\text { activities in destination from the } \\
\text { registration of mobile networks }\end{array}$ & $\begin{array}{l}\text { More accurate } \\
\text { Large number of people }\end{array}$ & $\begin{array}{l}\text { Possible invasion of the privacy } \\
\text { of the tourist } \\
\text { No access to user profile }\end{array}$ \\
\hline $\begin{array}{l}\text { C. Visitors registration using } \\
\text { Bluetooth technology }\end{array}$ & $\begin{array}{l}\text { Is anonymous, does not store } \\
\text { personal data of users }\end{array}$ & $\begin{array}{l}\text { The non-distinction between } \\
\text { tourists and residents }\end{array}$ \\
\hline $\begin{array}{l}\text { D. Patterns of tourist mobility, } \\
\text { based on geolocalized photographs }\end{array}$ & $\begin{array}{l}\text { Not invasion of the privacy } \\
\text { Low collection costs }\end{array}$ & $\begin{array}{l}\text { Only includes the travelers who } \\
\text { posted } \\
\text { Hard to create a tourist profile }\end{array}$ \\
\hline $\begin{array}{l}\text { E. Movement of tourist based in } \\
\text { geolocalized tweets }\end{array}$ & $\begin{array}{l}\text { Not invasion of the privacy } \\
\text { Low collection costs }\end{array}$ & $\begin{array}{l}\text { Only includes the travelers } \\
\text { who posted. }\end{array}$ \\
\hline $\begin{array}{l}\text { F. Analysis of movement pattern } \\
\text { from travel journals }\end{array}$ & $\begin{array}{l}\text { Less privacy issues because } \\
\text { it is voluntary }\end{array}$ & $\begin{array}{l}\text { Few tourists participate in due } \\
\text { to effort to fill in the details of each } \\
\text { activity } \\
\text { Fluctuation in data quality }\end{array}$ \\
\hline $\begin{array}{l}\text { G. Movement of tourist based } \\
\text { on digital records }\end{array}$ & $\begin{array}{l}\text { The combination of tools and } \\
\text { the accuracy }\end{array}$ & $\begin{array}{l}\text { The invasion of privacy } \\
\text { Difficulty in creating a tourist } \\
\text { profile }\end{array}$ \\
\hline $\begin{array}{l}\text { H. Tourist experience from travel } \\
\text { stories available on blogs }\end{array}$ & $\begin{array}{l}\text { Simpler and less expensive } \\
\text { to collect } \\
\text { The activities of the traveler } \\
\text { are not affected by observation }\end{array}$ & $\begin{array}{l}\text { The non-representative } \\
\text { sample }\end{array}$ \\
\hline $\begin{array}{l}\text { I. Patterns of movement of tourist } \\
\text { in a destination based on surveys }\end{array}$ & $\begin{array}{l}\text { Provide a better level of detail } \\
\text { than other methods. }\end{array}$ & $\begin{array}{l}\text { Difficulty to interview tourists } \\
\text { The quality and quantity } \\
\text { of the information collected }\end{array}$ \\
\hline $\begin{array}{l}\text { J. Models of tourist movements } \\
\text { with Markov chain based } \\
\text { on surveys }\end{array}$ & $\begin{array}{l}\text { It uses surveys } \\
\text { Provide a better level of detail } \\
\text { than other methods }\end{array}$ & $\begin{array}{l}\text { Difficulty to interview tourists } \\
\text { The quality and quantity } \\
\text { of the information collected }\end{array}$ \\
\hline $\begin{array}{l}\text { K. Spatio-temporal behavior } \\
\text { of tourist from the registration } \\
\text { of a space-time budget }\end{array}$ & $\begin{array}{l}\text { A survey is conducted based } \\
\text { on the place visited, the time } \\
\text { of the visit and the time spent. }\end{array}$ & $\begin{array}{l}\text { The quantity and quality } \\
\text { of the information collected }\end{array}$ \\
\hline
\end{tabular}


After reviewing the different methodological considerations, a classification of the tools used in the different case studies for the capture of information is proposed below in Figure 8. Other studies propose some classifications mainly based on the survey and alternatives of localization devices; we propose a classification according to two variables: level of interaction or intervention of the tourist and the level of incorporation or support in technology $[5,98,99,128]$.

The first variable corresponding to the interaction or intervention of the tourist, located on the horizontal axis, relates the necessary actions that are requested from the tourist to carry out in a conscious and collaborative way, investing time and effort. On the contrary without the direct intervention of the tourist, not beyond its activity within the destination. The second variable corresponding to the level of incorporation or support in technology, located on the vertical axis, refers to the need for use or intervention of a greater or lesser number of electronic devices, communications networks or processing services for the capture of information.

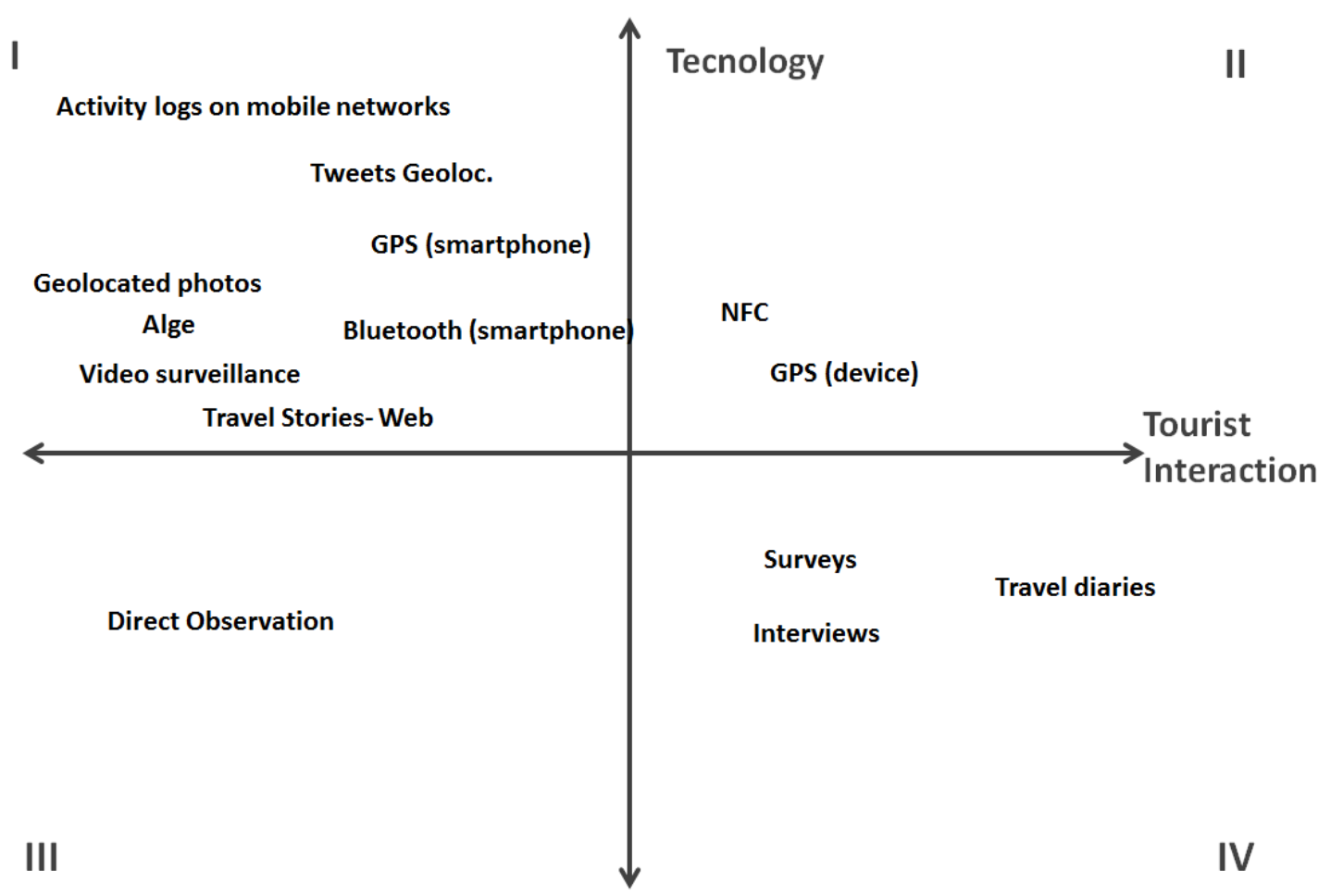

Figure 8. Classification of information capture tools.

The tools located in the first quadrant relate a higher level of technology incorporation and a lower level of interaction or collaboration of the tourist. Here we have geolocated tweets, activity logs on mobile networks, the Global Positioning System (GPS) for mobile phones (Smartphone), geolocated photos available on the internet, Bluetooth technology incorporated into mobile phones, Travel stories published on the web, video surveillance and the Alge system.

In the second quadrant, there are those tools that demand greater support or technological infrastructure, and more considerable effort from the tourists to generate the data; here you will find NFC (Near Field Communication) technology and the Global Positioning System (GPS) in a separate device. The third quadrant relates the tool that demands a lower level of interaction or collaboration of the tourist, not to give consent to participate in the study, which in some cases may be null; and that demands little infrastructure or technological support; here is located the direct observation. Finally, the fourth quadrant relates those tools that require a higher level of interaction or collaboration of the tourist and a minor incorporation or technological infrastructure, which in some cases becomes null; here are located: interviews, travel diaries and surveys. 
Among the tools that have so far been used to track this movement are geolocated tweets, activity logs on mobile networks, the Global Positioning System (GPS) for smartphones, geolocated photos available on the internet, the Bluetooth technology incorporated in mobile phones, travel stories published on the web, video surveillance and the Alge system, which have been analyzed from the perspective of tourist interaction at different levels or the complexity of technology. The analysis made allows to conclude that to obtain greater precision and detail of the data also more technology is required, which implies higher costs for any initiative in this respect.

From the perspective of methods for visualization and analysis of data, GIS systems prevail as an element for both visualization and processing. However, in recent years, there is a trend to consider new information visualization forms as visual alternatives to communicate data from tourism activity. As for alternatives of data analysis, we find the analysis of tourism statistics, which does not report the movements. Other approach are discrete models, having more relevance for the case of tourist movements, the Markov Chains. In general, beyond the use of new technological tools to capture data, tourism research requires methodologies to obtain and analyze data with a higher spatial and temporal resolution. Such methodology should also consider some tool that allows to obtain data of the movements of the tourists avoiding the invasion of the privacy of the tourist.

\section{Conclusions}

The analysis carried out on the terms of tourist movement and traceability allows us to classify two thematic cores: the movement of tourists and the tracking methodologies, as shown graphically in Figure 9 where the terms are represented, Tourist, Geography, Time, Space and Movement, which are at the intersection of the two sets. These concepts located at the intersection, can be studied from the focus of the movements of the tourists or the tracking methodologies; the latter, mainly related to the use of these terms in case studies.

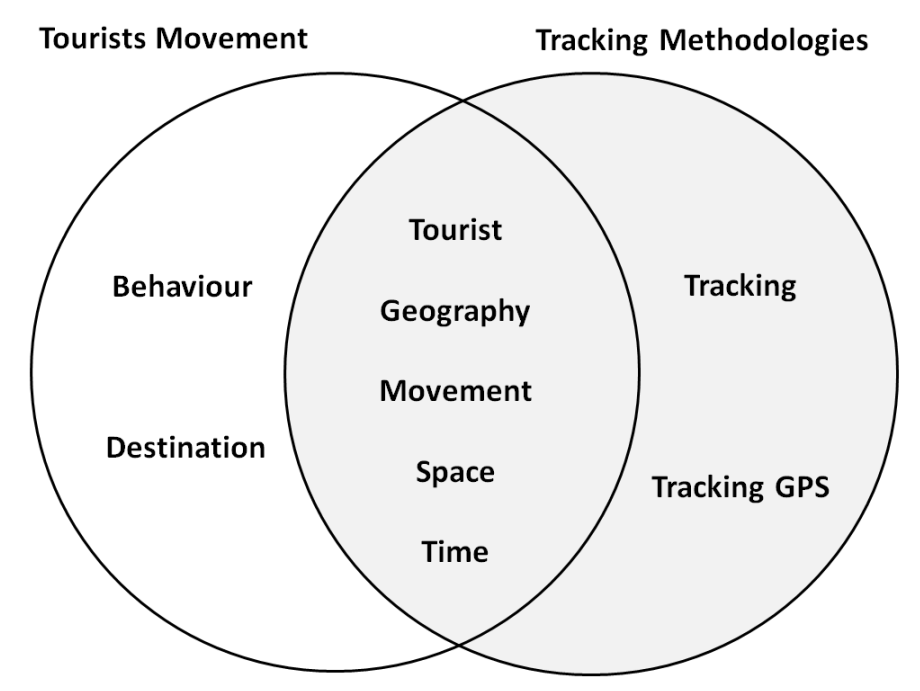

Figure 9. Tourism movement and traceability classification concepts.

The science mapping analysis has allowed the identification of the studies that have so far been developed around the analysis of the movements of the tourists as part of tourist behavior, and also to trace the studies that have applied the concept of traceability to the tourism. The latter have been non-existent, leaving a door open for future research to study the movement of tourists with traceability methodologies. In this study, the Citespace tool has facilitated the obtaining of the results, given its integrative nature of science mapping concepts and the graphic facilities.

In agreement with what Corral Marfil y Canoves found [125], this science mapping analysis has allowed corroborating that the majority of publications on tourist subjects are in journals not specialized in tourism like the case of the geography, where we can find much of the studies about 
tourists movements. However, by revealing with Citespace the most cited articles that constitute the basis of the publications, all the references found as more relevant belong to journals related to tourism.

The rate of growth in publications shows a tendency to publish in this area, which has been the most representative of the last decades, thus indicating that the study of the tourists' movements is a trend that is growing and becoming more relevant. The number of citations of the articles selected as relevant shows the basis for research from various approaches. The citation network of authors shows the trend of the most relevant publications, which together with the previous analysis of each publication, confirms the pioneering work on the subject. The automatic naming of clusters under the selected processing, confirms that the theme of movement analysis is a valid scientific trend, but the research-oriented under a traceability approach is zero, so this approach is constituted as novel and of potential contribution to knowledge.

In general, beyond the use of new technological tools to capture data, tourism research requires methodologies that allow to obtain and analyze data with a higher spatial and temporal resolution. As least intervention technologies from tourist area geolocated tweets, activity logs on mobile networks and geolocated photos are part of the most promising ones. In mobile technology alternatives, the most probable future will be marked with the combination of technologies as GPS, Bluetooth, and NFC.

The interest in introducing the concept of traceability to tourism goes beyond the use of a tool to capture information and focuses on a methodology. Its characteristic elements can contribute to the improvement of the methodological approaches used in other studies, also be helping in the solution of problems related to the accuracy and validity of the data collected with the traditional tools and those existing up to the date.

In a tourist destination the strategic decisions around the mobility of tourists are directly related to the infrastructure and services, since without these it is difficult to carry out tourist activities; these decisions have a positive or negative impact on the environmental, economic and social sustainability of the destination [30]; therefore a proper management and planning of the destination must consider not only meeting the needs of current residents and tourists, but also those of future generations [292].

Tourist mobility methodologies can track devices to find out how different types of tourists moved around each city [139]. All the people moving through the destination have considerable impacts on the economy, society, and the environment. The fact that more mobility means more impact on climate change [293] could be related to the movements in a tourism destination. In this way, planners should be aware of the amount of tourist they can manage and the places they must protect from that impact.

Finally, it is necessary to change the patterns of mobility into more sustainable ones. The study of tourist movements as part of tourist behavior allows us to understand the movement of people through space and time. The best way to do this is to create a system for measuring tourist traceability. In this way, planning tools can be made available to planners that can improve the efficiency of economic processes and control environmental and social impacts at each of the points of a most significant influx of tourists. In this sense, it will be possible to reduce the harmful effects of the tourist movement in terms of forecasting carrying capacity, for example, or to increase the positive ones, with actions such as the enhancement of tourist value and the marketing of resources and products with high demand. The next-generation of studies in this field could be enhanced with the introduction of the traceability concept and the intense use of mobile technology so the relations of the tourist with space can be managed with the mobile technologies found.

Author Contributions: Conceptualization, G.R.-G.; Formal analysis, A.C.-A.; Investigation, A.C.-A.; Methodology, G.R.-G.; Resources, A.M.-M.; Supervision, L.F.-M. and A.M.-M.; Validation, L.F.-M. and A.M.-M.; Visualization, L.F.-M.; Writing-Original draft, A.C.-A., A.M.-M. and G.R.-G.; Writing-Review \& editing, A.C.-A., L.F.-M. and G.R.-G.

Funding: Universidad del Cauca (501100005682).

Conflicts of Interest: The authors declare no conflict of interest. 


\section{References}

1. Tiwari, S.; Kaushik, S.; Tiwari, S.; Jagwani, P. Location based recommender systems: Architecture, trends and research areas. In Proceedings of the IET International Conference on Wireless Communications and Applications (ICWCA 2012), Kuala Lumpur, Malaysia, 8-10 October 2012; pp. 1-8. [CrossRef]

2. Tiwari, S.; Kaushik, S. Information Enrichment for Tourist Spot Recommender System Using Location Aware Crowdsourcing. In Proceedings of the 2014 IEEE 15th International Conference on Mobile Data Management, Brisbane, Australia, 14-18 July 2014; Volume 2, pp. 11-14, doi:10.1109/MDM.2014.59. [CrossRef]

3. Pettersson, R.; Zillinger, M. Time and Space in Event Behaviour: Tracking Visitors by GPS. Tour. Geogr. 2011, 13, 1-20, doi:10.1080/14616688.2010.529932. [CrossRef]

4. O'Connor, A.; Zerger, A.; Itami, B. Building better agents: Geo-temporal tracking and analysis of tourist behavior. MODSIM 2003 2003, 3, 1148-1153

5. Shoval, N.; Isaacson, M. Application of Tracking Technologies to the Study of Pedestrian Spatial Behavior. Prof. Geogr. 2006, 58, 172-183, doi:10.1111/j.1467-9272.2006.00524.x. [CrossRef]

6. Shoval, N. Tracking technologies and urban analysis. Cities 2008, 25, 21-28. [CrossRef]

7. Schaick, J.; Spek, S.C. Urbanism on Track: Application of Tracking Technologies in Urbanism; IOS Press: Clifton, VA, USA, 2008; Volume 1.

8. Lau, G.; McKercher, B. Understanding Tourist Movement Patterns in a Destination: A GIS Approach. Tour. Hosp. Res. 2006, 7, 39-49, doi:10.1057/palgrave.thr.6050027. [CrossRef]

9. Shoval, N.; Schvimer, Y.; Tamir, M. Real-Time Measurement of Tourists Objective and Subjective Emotions in Time and Space. J. Travel Res. 2017, 0047287517691155, doi:10.1177/0047287517691155. [CrossRef]

10. Van der Knaap, W.G. Research report: GIS oriented analysis of tourist time space patterns to support sustainable tourism development. Tour. Geogr. 1999, 1, 56-69, doi:10.1080/14616689908721294. [CrossRef]

11. Pugh, N.R. Principles of product traceability. Am. Soc. Qual. Control 1973, 4, 65-69.

12. Monteiro, D.M.S.; Caswell, J.A. Traceability adoption at the farm level: An empirical analysis of the Portuguese pear industry. Food Policy 2009, 34, 94-101, doi:10.1016/j.foodpol.2008.07.003. [CrossRef]

13. Smallwood, C.B.; Beckley, L.E.; Moore, S.A. An analysis of visitor movement patterns using travel networks in a large marine park, north-western Australia. Tour. Manag. 2012, 33, 517-528.10.1016/j.tourman.2011.06.001.

14. Butler, R.W. Sustainable tourism: A state-of-the-art review. Tour. Geogr. 1999, 1, 7-25. [CrossRef]

15. Edgell, D.L., Sr. Managing Sustainable Tourism: A Legacy for the Future; Routledge: Abingdon, UK, 2016.

16. Eckert, C.; Pechlaner, H. Alternative Product Development as Strategy Towards Sustainability in Tourism: The Case of Lanzarote. Sustainability 2019, 11, 3588. [CrossRef]

17. Hashemkhani Zolfani, S.; Sedaghat, M.; Maknoon, R.; Zavadskas, E.K. Sustainable tourism: A comprehensive literature review on frameworks and applications. Econ. Res. Ekon. Istraz. 2015, 28, 1-30. [CrossRef]

18. Jovicic, D.Z. Key issues in the implementation of sustainable tourism. Curr. Issues Tour. 2014, 17, $297-302$. [CrossRef]

19. Keul, A. Field research on tourism: The Salzburg Tracking Project. Gr. Z. Angew. Soz. 1996, 27, 51-56.

20. Fennell, D.A. A tourist space-time budget in the Shetland Islands. Ann. Tour. Res. 1996, 23, 811-829, doi:10.1016/0160-7383(96)00008-4. [CrossRef]

21. McKercher, B.; Lau, G. Movement patterns of tourists within a destination. Tour. Geogr. 2008, 10, 355-374, doi:10.1080/14616680802236352. [CrossRef]

22. Asakura, Y.; Iryo, T. Analysis of tourist behaviour based on the tracking data collected using a mobile communication instrument. Transp. Res. Part A Policy Pract. 2007, 41, 684-690. [CrossRef]

23. Lew, A.; McKercher, B. Modeling tourist movements-A local destination analysis. Ann. Tour. Res. 2006, 33, 403-423, doi:10.1016/j.annals.2005.12.002. [CrossRef]

24. Baraglia, R.; Muntean, C.I.; Nardini, F.M.; Silvestri, F. LearNext: Learning to Predict Tourists Movements. In Proceedings of the 22nd ACM International Conference on Information \& Knowledge Management, San Francisco, CA, USA, 27 October-1 November 2013; ACM: New York, NY, USA, 2013; pp. 751-756, doi:10.1145/2505515.2505656. [CrossRef]

25. Ruhanen, L. Strategic visioning: Integrating sustainable development principles in tourism destination planning. Acta Tur. 2012, 24, 149-176.

26. McCamley, C.; Gilmore, A. Strategic marketing planning for heritage tourism: A conceptual model and empirical findings from two emerging heritage regions. J. Strateg. Mark. 2018, 26, 156-173. [CrossRef] 
27. Shirazi, S.F.M.; Som, A.P.M. Destination Management and Relationship Marketing: Two Major Factors to Achieve Competitive Advantage. J. Relatsh. Mark. 2011, 10, 76-87. [CrossRef]

28. Dwyer, L.; Edwards, D.; Mistilis, N.; Roman, C.; Scott, N. Destination and enterprise management for a tourism future. Tour. Manag. 2009, 30, 63-74, doi:10.1016/j.tourman.2008.04.002. [CrossRef]

29. Beeco, J.A.; Brown, G. Integrating space, spatial tools, and spatial analysis into the human dimensions of parks and outdoor recreation. Appl. Geogr. 2013, 38, 76-85, doi:10.1016/j.apgeog.2012.11.013. [CrossRef]

30. Scuttari, A.; Lucia, M.D.; Martini, U. Integrated planning for sustainable tourism and mobility. A tourism traffic analysis in Italy's South Tyrol region. J. Sustain. Tour. 2013, 21, 614-637. [CrossRef]

31. Jin, Q.; Hu, H.; Kavan, P. Factors Influencing Perceived Crowding of Tourists and Sustainable Tourism Destination Management. Sustainability 2016, 8, 976, doi:10.3390/su8100976. [CrossRef]

32. Mings, R.C.; Mchugh, K.E. The Spatial Configuration of Travel to Yellowstone National Park. J. Travel Res. 1992, 30, 38-46, doi:10.1177/004728759203000406. [CrossRef]

33. Lue, C.C.; Crompton, J.L.; Fesenmaier, D.R. Conceptualization of multi-destination pleasure trips. Ann. Tour. Res. 1993, 20, 289-301, doi:10.1016/0160-7383(93)90056-9. [CrossRef]

34. Oppermann, M. A Model of Travel Itineraries. J. Travel Res. 1995, 33, 57-61. [CrossRef]

35. Flognfeldt, T. Traveler Geographic Origin and Market Segmentation: The Multi Trips Destination Case. J. Travel Tour. Mark. 1999, 8, 111-124, doi:10.1300/J073v08n01_07. [CrossRef]

36. Sriram, N.; Lew, A.; Raguraman, K. Gateways, hubs and destinations: Transportation hierarchies in Southeast Asia. In Tourism Managements and Policy: Perspectives from Singapore; World Scientific Publishing Co. Pte. Ltd.: Singapore, 2001; pp. 55-89.

37. Connell, J.; Page, S.J. Exploring the spatial patterns of car-based tourist travel in Loch Lomond and Trossachs National Park, Scotland. Tour. Manag. 2008, 29, 561-580, doi:10.1016/j.tourman.2007.03.019. [CrossRef]

38. Dickinson, J.E.; Filimonau, V.; Cherrett, T.; Davies, N.; Norgate, S.; Speed, C.; Winstanley, C. Understanding temporal rhythms and travel behaviour at destinations: Potential ways to achieve more sustainable travel. J. Sustain. Tour. 2013, 21, 1070-1090, doi:10.1080/09669582.2013.802328. [CrossRef]

39. Paunovic, I.; Jovanovic, V. Implementation of Sustainable Tourism in the German Alps: A Case Study. Sustainability 2017, 9, 226, doi:10.3390/su9020226. [CrossRef]

40. Bratucu, G.; Baltescu, C.A.; Neacu, N.A.; Bocor, D.; ierean, O.M.; Madar, A. Approaching the Sustainable Development Practices in Mountain Tourism in the Romanian Carpathians. Sustainability 2017, 9, 2051, doi:10.3390/su9112051. [CrossRef]

41. Lew, A.A.; McKercher, B. Trip destinations, gateways and itineraries: The example of Hong Kong. Tour. Manag. 2002, 23, 609-621, doi:10.1016/S0261-5177(02)00026-2. [CrossRef]

42. Hall, C.M.; Lew, A.A. Understanding and Managing Tourism Impacts: An Integrated Approach (Contemporary Geographies of Leisure, Tourism and Mobility), 1st ed.; Routledge: Abingdon, UK, 2009.

43. Mckercher, B.; Lew, A.A. Distance Decay and the Impact of Effective Tourism Exclusion Zones on International Travel Flows. J. Travel Res. 2003, 42, 159-165, doi:10.1177/0047287503254812. [CrossRef]

44. Ho, G.; McKercher, B. A Comparison of Long-Haul and Short-Haul Business Tourists of Hong Kong. Asia Pac. J. Tour. Res. 2014, 19, 342-355, doi:10.1080/10941665.2012.746235. [CrossRef]

45. Yan, Y.Q.; Zhang, H.Q.; Ye, B.H. Assessing the impacts of the high-speed train on tourism demand in China. Tour. Econ. 2014, 20, 157-169, doi:10.5367/te.2013.0260. [CrossRef]

46. Albrecht, J.N. Micro-mobility patterns and service blueprints as foundations for visitor management planning. J. Sustain. Tour. 2014, 22, 1052-1070, doi:10.1080/09669582.2013.847945. [CrossRef]

47. Meijles, E.; de Bakker, M.; Groote, P.; Barske, R. Analysing hiker movement patterns using GPS data: Implications for park management. Comput. Environ. Urban Syst. 2013, 47, 44-57. [CrossRef]

48. Taczanowska, K.; Muhar, A.; Brandenburg, C. Potential and limitations of GPS tracking for monitoring spatial and temporal aspects of visitor behaviour in recreational areas. In Proceedings of the Fourth International Conference on Monitoring and Management of Visitor Flows in Recreational and Protected Areas, Montecatini Terme, Italy, 14 October 2008; Volume 14, p. 451.

49. Dye, A.S.; Shaw, S.L. A GIS-based spatial decision support system for tourists of Great Smoky Mountains National Park. J. Retail. Consum. Serv. 2007, 14, 269-278, doi:10.1016/j.jretconser.2006.07.005. [CrossRef]

50. Aminu, M.; Ludin, A.; Matori, A.N.; Wan Yusof, K.; Dano, L.; Chandio, I. A spatial decision support system (SDSS) for sustainable tourism planning in Johor Ramsar sites, Malaysia. Environ. Earth Sci. 2013, 70, 1113-1124, doi:10.1007/s12665-012-2198-6. [CrossRef] 
51. Holyoak, N.; Carson, D.; Schmallegger, D. VRUMTM: A Tool for Modelling Travel Patterns of Self-Drive Tourists. In Information and Communication Technologies in Tourism 2009; Hopken, W., Gretzel, U., Law, R., Eds.; Springer: Vienna, Austria, 2009; pp. 237-247, doi:10.1007/978-3-211-93971-0_20.

52. Carson, D.A.; Carson, D.B.; Lundmark, L. Tourism and Mobilities in Sparsely Populated Areas: Towards a Framework and Research Agenda. Scand. J. Hosp. Tour. 2014, 14, 353-366. [CrossRef]

53. Wolf, I.D.; Hagenloh, G.; Croft, D.B. Visitor monitoring along roads and hiking trails: How to determine usage levels in tourist sites. Tour. Manag. 2012, 33, 16-28, doi:10.1016/j.tourman.2011.01.019. [CrossRef]

54. Wolf, I.D.; Stricker, H.K.; Hagenloh, G. Interpretive media that attract park visitors and enhance their experiences: A comparison of modern and traditional tools using \{GPS\} tracking and \{GIS\} technology. Tour. Manag. Perspect. 2013, 7, 59-72, doi:10.1016/j.tmp.2013.04.002. [CrossRef]

55. Freuler, B.; Hunziker, M. Recreation activities in protected areas: Bridging the gap between the attitudes and behaviour of snowshoe walkers. For. Snow Landsc. Res. 2007, 81, 191-206

56. Booth, J.E.; Gaston, K.J.; Armsworth, P.R. Public understanding of protected area designation. Biol. Conserv. 2009, 142, 3196-3200, doi:10.1016/j.biocon.2009.07.024. [CrossRef]

57. Tanner-McAllister, S.; Rhodes, J.; Hockings, M. Community and park manager's perceptions of protected area management: A southeast Queensland study. Australas. J. Environ. Manag. 2014, 21, 320-336, doi:10.1080/14486563.2014.932720. [CrossRef]

58. Rupf, R.; Wyttenbach, M.; Köchli, D.; Hediger, M.; Lauber, S.; Ochsner, P.; Graf, R. Assessing the spatio-temporal pattern of winter sports activities to minimize disturbance in capercaillie habitats. J. Prot. Mt. Areas Res. Manag. 2011, 3, 23-32. [CrossRef]

59. Higham, J.; Inge Vistad, O. Tourism in Protected Natural Areas: The Nordic-Baltic Context. Scand. J. Hosp. Tour. 2011, 11, 1-12, doi:10.1080/15022250.2011.638208. [CrossRef]

60. Lyon, K.; Cottrell, S.P.; Siikamki, P.; Van Marwijk, R. Biodiversity Hotspots and Visitor Flows in Oulanka National Park, Finland. Scand. J. Hosp. Tour. 2011, 11, 100-111, doi:10.1080/15022250.2011.629909. [CrossRef]

61. Orellana, D.; Bregt, A.K.; Ligtenberg, A.; Wachowicz, M. Exploring visitor movement patterns in natural recreational areas. Tour. Manag. 2012, 33, 672-682, doi:10.1016/j.tourman.2011.07.010. [CrossRef]

62. Paunovic, I.; Jovanovic, V. Sustainable mountain tourism in word and deed: A comparative analysis in the macro regions of the Alps and the Dinarides. Acta Geogr. Slov. 2019, 59. [CrossRef]

63. Opara, L.U.; Mazaud, F. Food traceability from field to plate. Outlook Agric. 2001, 30, 239-247. [CrossRef]

64. Gunawan, I.; Vanany, I.; Widodo, E. The influence of traceability system practice to product recall capability in bulk food industry: Observation and interview. In Proceedings of the 2017 IEEE International Conference on Industrial Engineering and Engineering Management (IEEM), Singapore, 10-13 December 2017; pp. 1688-1692.

65. González-Amarillo, C.A.; Corrales-Muñoz, J.C.; Mendoza-Moreno, M.Á.; Hussein, A.F.; Arunkumar, N.; Ramirez-González, G. An IoT-Based Traceability System for Greenhouse Seedling Crops. IEEE Access 2018, 6, 67528-67535. [CrossRef]

66. Jiang, J.A.; Lin, T.S.; Wang, C.H.; Liao, M.S.; Chou, C.Y.; Chen, C.T. Integration of an automatic agricultural and livestock production management system and an agriculture and food traceability system based on the Internet of Things technology. In Proceedings of the 2017 Eleventh International Conference on Sensing Technology (ICST), Sydney, Australia, 4-6 December 2017; pp. 1-7.

67. Moretti, V.; Turchini, G.; Bellagamba, F.; Caprino, F. Traceability Issues in Fishery and Aquaculture Products. Vet. Res. Commun. 2003, 27, 497-505, doi:10.1023/B:VERC.0000014207.01900.5c. [CrossRef] [PubMed]

68. Thompson, M.; Sylvia, G.; Morrissey, M.T. Seafood Traceability in the United States: Current Trends, System Design, and Potential Applications. Compr. Rev. Food Sci. Food Saf. 2005, 4, 1-7. [CrossRef]

69. Wang, N.; Zhang, N.; Wang, M. Wireless sensors in agriculture and food industry-Recent development and future perspective. Comput. Electron. Agric. 2006, 50, 1-14, doi:10.1016/j.compag.2005.09.003. [CrossRef]

70. Schroder, U. Challenges in the Traceability of Seafood. J. Verbrauch. Lebensm. 2008, 3, 45-48. [CrossRef]

71. Storoya, J.; Thakura, M.; Olsen, P. The TraceFood Framework-Principles and guidelines for implementing traceability in food value chains. J. Food Eng. 2013, 115, 41-48, doi:10.1016/j.jfoodeng.2012.09.018. [CrossRef]

72. Regattieri, A.; Gamberi, M.; Manzini, R. Traceability of food products: General framework and experimental evidence. J. Food Eng. 2007, 81, 347-356, doi:10.1016/j.jfoodeng.2006.10.032. [CrossRef] 
73. Costa, C.; Antonucci, F.; Pallottino, F.; Aguzzi, J.; Sarria, D.; Menesatti, P. A Review on Agri-food Supply Chain Traceability by Means of RFID Technology. Food Bioprocess Technol. 2013, 6, 353-366, doi:10.1007/s11947-012-0958-7. [CrossRef]

74. Lindvall, M.; Sandahl, K. Practical Implications of Traceability. Softw. Pract. Exper. 1996, 26, 1161-1180, doi:10.1002/(SICI)1097-024X(199610)26:10<1161::AID-SPE58>3.0.CO;2-X. [CrossRef]

75. Moe, T. Perspectives on traceability in food manufacture. Trends Food Sci. Technol. 1998, 9, 211-214, doi:10.1016/S0924-2244(98)00037-5. [CrossRef]

76. Kim, H.; Fox, M.; Gruninger, M. An ontology of quality for enterprise modelling. In Proceedings of the 4th IEEE Workshop on Enabling Technologies: Infrastructure for Collaborative Enterprises (WET ICE '95), Berkeley Springs, WV, USA, 20-22 April 1995; pp. 105-116, doi:10.1109/ENABL.1995.484554. [CrossRef]

77. Storøy, J.; Senneset, G.; Forås, E.; Olsen, P.; Karlsen, K.; Frederiksen, M.; Børresen, T. Improving traceability in seafood production. In Improving Seafood Products for the Consumer; British Welding Research Association: Cambridge, UK, 2008; pp. 516-538.

78. Keller, G.; Niuttgens, M. AW Scheer. semantische Processmodellierung auf der Grundlage Ereignisgesteuerter Processketten (EPK); Institut für Wirtschaftsinformatik, Universität des Saarlandes: Saarbrücken, Germany, 1992.

79. Ziemann, J.; Werth, D.; Matheis, T.; Kahl, T. Towards Tool Support for Integrated Modeling of Private and Public Business Processes. In Proceedings of the 16th IEEE International Workshops on Enabling Technologies: Infrastructure for Collaborative Enterprises (WETICE 2007), Evry, France, 18-20 June 2007; pp. 383-386, doi:10.1109/WETICE.2007.4407194. [CrossRef]

80. Kiepuszewski, B.; ter Hofstede, A.; van der Aalst, W. Fundamentals of control flow in workflows. Acta Inform. 2003, 39, 143-209, doi:10.1007/s00236-002-0105-4. [CrossRef]

81. Van der Aalst, W.; ter Hofstede, A.; Weske, M. Business Process Management: A Survey. In Business Process Management; van der Aalst, W., Weske, M., Eds.; Springer: Berlin/Heidelberg, Germany, 2003; Volume 2678, pp. 1-12, doi:10.1007/3-540-44895-0_1.

82. Van der Aalst, W.M. Business process management: A comprehensive survey. ISRN Softw. Eng. 2013, 2013, 507984. [CrossRef]

83. Bevilacqua, M.; Ciarapica, F.; Giacchetta, G. Business process reengineering of a supply chain and a traceability system: A case study. J. Food Eng. 2009, 93, 13-22. [CrossRef]

84. EAN Belgium. Best Practices in Traceability; Technical Report; EAN Belgium: Luxembourg, 2003.

85. GS1. GS1 Global Traceability Standard for Healthcare (GTSH) Implementation Guide; Technical Report; GS1: Brussels, Belgium, 2009.

86. GS1. Traceability for Fresh Fruits and Vegetables Implementation Guide; Technical Report; GS1: Brussels, Belgium, 2010.

87. GS1. Wine Supply Chain Traceability. GS1 Implementation Guide; Technical Report; GS1: Brussels, Belgium, 2005.

88. BRIDGE Project. BRIDGE: Building Radio Frequency Identification for the Global Environment; University of Cambridge: Cambridge, UK, 2015.

89. EC. BRIDGE: Building Radio Frequency IDentification for the Global Environment. Project Website. 2015. Available online: http:/ / www.bridge-project.eu/(accessed on 4 July 2019).

90. Ilie-Zudor, E.; Kemény, Z.; Van Blommestein, F.; Monostori, L.; Van Der Meulen, A. A survey of applications and requirements of unique identification systems and RFID techniques. Comput. Ind. 2011, 62, 227-252, doi:10.1016/j.compind.2010.10.004. [CrossRef]

91. Assimakopoulos, A.M.; Puech, C.; Meinkoehn, F.; Gallicchio, E.; Grotiuz, I. Local-Communities Insertion Network Para America Latina: The Link-All System. In Proceedings of the ICHIM 05 Digital Culture and Heritage/Patrimoine culturel et numérique, Paris, France, 21-23 September 2005.

92. Hurtado, J.; Maya, N.; Ramírez, G.; Caicedo, O. Resultados, Impacto y Sostenibilidad de LINK-ALL. In Alianza Para la Sociedad de la Información (@LIS): Experiencias y Realizaciones de la Universidad del Cauca; Rendón, A., Caicedo, O., Solarte, M., Eds.; Universidad del Cauca: Cauca, Colombia, 2008; pp. 251-258.

93. Caicedo, O.; Martinez, F.; Hurtado, J.; Ramirez, G. Wireless Trace Service for Latin American Craft Sector. In Proceedings of the 2006 Wireless Telecommunications Symposium, Pomana, CA, USA, 27-29 April 2016; pp. 1-8, doi:10.1109/WTS.2006.334526. [CrossRef]

94. EPCGlobal. Sitio Web Oficial. 2011. Available online: http://www.gs1.org/epcglobal (accessed on 4 July 2019).

95. Kong, H.L.; Li, J.H. Application Review of the Global Identification System (EAN. UCC System) in the Traceability of the Food Safety Supply Chain. Food Sci. 2004, 6, 49. 
96. Folinas, D.; Manikas, I.; Manos, B. Traceability data management for food chains. Br. Food J. 2006, 108, 622-633. [CrossRef]

97. Ramirez-Gonzalez, G.; Munoz-Organero, M.; Kloos, C.D.; Chantre, A. Exploring NFC Interactive Panel. In Proceedings of the 5th Annual International Conference on Mobile and Ubiquitous Systems: Computing, Networking, and Services, Belgium, Belgium, 21-25 July 2008, doi:10.4108/ICST.MOBIQUITOUS2008.3948.

98. Concha-Agredo, E.A.; Martinez-Acosta, L.C.; Chantre, A.; Ramirez-Gonzalez, G. Pervasive NFC-based solution for the analysis of tourism data in an environment of smart cities. Sist. Telemat. 2015, 13, 41-60, doi:10.18046/syt.v13i32.2016. [CrossRef]

99. Silva-Pedroza, D.; Marin-Calero, R.; Ramirez-Gonzalez, G. NFC Evaluation in the Development of Mobile Applications for MICE in Tourism. Sustainability 2017, 9, 1937, doi:10.3390/su9111937. [CrossRef]

100. Gonzalez, G.R.; Organero, M.M.; Kloos, C.D. Early Infrastructure of an Internet of Things in Spaces for Learning. In Proceedings of the 2008 Eighth IEEE International Conference on Advanced Learning Technologies, Santander, Spain, 1-5 July 2008; pp. 381-383, doi:10.1109/ICALT.2008.210. [CrossRef]

101. Jara, A.; Zamora, M.; Skarmeta, A. An Architecture Based on Internet of Things to Support Mobility and Security in Medical Environments. In Proceedings of the 2010 7th IEEE Consumer Communications and Networking Conference, Las Vegas, NV, USA, 9-12 January 2010; pp. 1-5. [CrossRef]

102. Borgman, C.L.; Furner, J. Scholarly communication and bibliometrics. Annu. Rev. Inf. Sci. Technol. 2002, 36, 2-72, doi:10.1002/aris.1440360102. [CrossRef]

103. Grivel, L.; Polanco, X.; Kaplan, A. A computer system for big scientometrics at the age of the World Wide Web. Scientometrics 1997, 40, 493-506. [CrossRef]

104. Santhanakarthikeyan, S.; Padma, P.; Veeramani, M.; Ravikrishnan, D. Scientometrics Study on Web: Tools and Techniques. Scientometrics 1960, 4, 40-45.

105. Garfield, E. Citation indexes for science. A new dimension in documentation through association of ideas. Int. J. Epidemiol. 2006, 35, 1123-1127, doi:10.1093/ije/dyl189. [CrossRef] [PubMed]

106. Small, H.; Greenlee, E. Citation context analysis of a co-citation cluster: Recombinant-DNA. Scientometrics 1980, 2, 277-301. [CrossRef]

107. Marshakova, I. System of document connection based on references. Nauchno-Tek. Inf. 1973, 2, 3-8.

108. Muñoz, L.A.; Bolívar, M.P.R.; Cobo, M.J.; Herrera-Viedma, E. Science Mapping Tools: Their Application to e-Government Field. In Proceedings of the 17th International Digital Government Research Conference on Digital Government Research, Shanghai, China, 8-10 June 2016; ACM: New York, NY, USA, 2016; pp. 194-201, doi:10.1145/2912160.2912172. [CrossRef]

109. Morris, S.A.; Van der Veer Martens, B. Mapping research specialties. Annu. Rev. Inf. Sci. Technol. 2008, 42, 213-295, doi:10.1002/aris.2008.1440420113. [CrossRef]

110. Van Eck, N.J.; Waltman, L. Software survey: VOSviewer, a computer program for bibliometric mapping. Scientometrics 2010, 84, 523-538. [CrossRef]

111. Borner, K.; Chen, C.; Boyack, K.W. Visualizing knowledge domains. Annu. Rev. Inf. Sci. Technol. 2003, 37, 179-255, doi:10.1002/aris.1440370106. [CrossRef]

112. Noyons, E.; Moed, H.; Luwel, M. Combining mapping and citation analysis for evaluative bibliometric purposes: A bibliometric study. J. Am. Soc. Inf. Sci. 1999, 50, 115-131. [CrossRef]

113. Persson, O.; Danell, R.; Schneider, J.W. How to use Bibexcel for various types of bibliometric analysis. Celebr. Sch. Commun. Stud. 2009, 5, 9-24.

114. Chen, C. Searching for intellectual turning points: Progressive knowledge domain visualization. Proc. Natl. Acad. Sci. USA 2004, 101, 5303-5310, doi:10.1073/pnas.0307513100. [CrossRef] [PubMed]

115. Eck, N.J.V.; Waltman, L. CitNetExplorer: A new software tool for analyzing and visualizing citation networks. J. Informetr. 2014, 8, 802-823, doi:10.1016/j.joi.2014.07.006. [CrossRef]

116. Leydesdorff, L. Leydesdorff Software. Available online: https://www.leydesdorff.net/software.htm (accessed on 4 July 2019).

117. Matheo-Software Team. Matheo Analyzer; Matheo-Software Team. Available online: https://www.matheosoftware.com/matheo-analyzer/ (accessed on 4 July 2019).

118. Börner, K.; Polley, D.E. Visual Insights: A Practical Guide to Making Sense of Data; MIT Press: Cambridge, MA, USA, 2014.

119. Cobo, M.; López-Herrera, A.; Herrera-Viedma, E.; Herrera, F. SciMAT: A new science mapping analysis software tool. J. Am. Soc. Inf. Sci. Technol. 2012, 63, 1609-1630, doi:10.1002/asi.22688. [CrossRef] 
120. Ruiz-Rosero, J.; Ramirez-Gonzalez, G.; Williams, J.M.; Liu, H.; Khanna, R.; Pisharody, G. Internet of Things: A Scientometric Review. Symmetry 2017, 9, 301, doi:10.3390/sym9120301. [CrossRef]

121. Zhang, S.J.; Lyu, P.H.; Yan, Y. Global geographical and scientometric analysis of tourism-themed research. Scientometrics 2015, 105, 385-401. [CrossRef]

122. Zhang, Q.; Wang, Q.; Hao, J.X.; Yu, Y. Mapping smart tourism research in China: A semantic and social network analysis using CiteSpace. In Proceedings of the 2016 13th International Conference on Service Systems and Service Management (ICSSSM), Kunming, China, 24-26 June 2016; pp. 1-5, doi:10.1109/ICSSSM.2016.7538622. [CrossRef]

123. Fang, Y.; Yin, J.; Wu, B. Climate change and tourism: A scientometric analysis using CiteSpace. J. Sustain. Tour. 2018, 26, 108-126, doi:10.1080/09669582.2017.1329310. [CrossRef]

124. Li, X.; Ma, E.; Qu, H. Knowledge mapping of hospitality research-A visual analysis using CiteSpace. Int. J. Hosp. Manag. 2017, 60, 77-93, doi:10.1016/j.ijhm.2016.10.006. [CrossRef]

125. Marfil, J.A.C.; Valiente, G.C. La investigación turística publicada en revistas turísticas y no turísticas: Análisis bibliométrico de la producción de las universidades catalanas. Cuad. Tur. 2013, 31, 55-81.

126. Leiva Olivencia, J.L.; Guevara Plaza, A.; Rossi Jimenez, C. Generation of recommendations in an Augmented Reality system applied to tourism based on the context. Pasos-Rev. Tur. Patrim. Cult. 2015, 13, 649-668.

127. Shoval, N.; Schvimer, Y.; Tamir, M. Tracking technologies and urban analysis: Adding the emotional dimension. Cities 2018, 72, 34-42. [CrossRef]

128. Zheng, Y.T.; Li, Y.; Zha, Z.J.; Chua, T.S. Mining Travel Patterns from GPS-Tagged Photos. In Advances in Multimedia Modeling, PT I; Lee, K.T., Tsai, W.H., Liao, H.Y.M., Chen, T., Hsieh, J.W., Tseng, C.C., Eds.; Springer: Berlin, Germany, 2011; Volume 6523, pp. 262-272.

129. Basiron, N.F.Z.; Ahmad, A.; Masron, T. Spatial Analysis of International Tourist Movement to Langkawi for 2010 and 2011. In Proceedings of the SHS Web of Conferences, Paris, France, 1 January 2014; Volume 12, p. 01066.

130. Zoltan, J.; McKercher, B. Analysing intra-destination movements and activity participation of tourists through destination card consumption. Tour. Geogr. 2015, 17, 19-35. [CrossRef]

131. Ahas, R.; Aasa, A.; Mark, U.; Pae, T.; Kull, A. Seasonal tourism spaces in Estonia: Case study with mobile positioning data. Tour. Manag. 2007, 28, 898-910, doi:10.1016/j.tourman.2006.05.010. [CrossRef]

132. Brilhante, I.; Macedo, J.; Nardini, F.; Perego, R.; Renso, C. TripBuilder: A Tool for Recommending Sightseeing Tours. In Proceedings of the European Conference on Information Retrieval, Amsterdam, The Netherlands, 13-16 April 2014; Rijke, M., Kenter, T., Vries, A., Zhai, C.X., Jong, F., Radinsky, K., Hofmann, K., Eds.; Springer International Publishing: Cham, Switzerland, 2014; pp. 771-774.

133. Cai, G.; Hio, C.; Bermingham, L.; Lee, K.; Lee, I. Mining Frequent Trajectory Patterns and Regions-of-Interest from Flickr Photos. In Proceedings of the 2014 47th Hawaii International Conference on System Sciences (HICSS), Los Alamitos, CA, USA, 6-9 January 2014; pp. 1454-1463.

134. Gabrielli, L.; Rinzivillo, S.; Ronzano, F.; Villatoro, D. From tweets to semantic trajectories: Mining anomalous urban mobility patterns. In Proceedings of the International Workshop on Citizen in Sensor Networks, Barcelona, Spain, 19 September 2013; Nin, J., Villatoro, D., Eds.; Springer International Publishing: Cham, Switzerland, 2014; pp. 26-35.

135. Hummel, K.A.; Hess, A. Movement activity estimation and forwarding effects for opportunistic networking based on urban mobility traces. Wirel. Commun. Mob. Comput. 2013, 13, 343-360. [CrossRef]

136. Masiero, L.; Zoltan, J. Tourists intra-destination visits and transport mode: A bivariate probit model. Ann. Tour. Res. 2013, 43, 529-546, doi:10.1016/j.annals.2013.05.014. [CrossRef]

137. Bianchi, R.V.; Stephenson, M.L. Deciphering tourism and citizenship in a globalized world. Tour. Manag. 2013, 39, 10-20, doi:10.1016/j.tourman.2013.03.006. [CrossRef]

138. Restrepo, E.; Moreno, F.; Sanchez Lasheras, F. Identification of frequent touristic routes using the SMoT algorithm. In Proceedings of the 11th International Conference of Numerical Analysis and Applied Mathematics 2013, Rhodes, Greece, 21-27 September 2013; Volume 1558, pp. 2325-2328.

139. Edwards, D.; Griffin, T. Understanding tourists spatial behaviour: GPS tracking as an aid to sustainable destination management. J. Sustain. Tour. 2013, 21, 580-595, doi:10.1080/09669582.2013.776063. [CrossRef]

140. Zhao, J.; Forer, P.; Sun, Q.; Simmons, D. Multiple-view strategies for enhanced understanding of dynamic tourist activity through geovisualization at regional and national scales. Cartogr. Geogr. Inf. Sci. 2013, 40, 349-360, doi:10.1080/15230406.2013.783449. [CrossRef] 
141. Elragal, A.; El-Gendy, N. Trajectory data mining: Integrating semantics. J. Enterp. Inf. Manag. 2013, 26, 516-535. [CrossRef]

142. Mladenovic, V.; Lutovac, M.M.; Lutovac, M.D. Electronic Tour Guide for Android Mobile Platform with Multimedia Travel Book. In Proceedings of the 2012 20th Telecommunications Forum (TELFOR), Belgrade, Serbia, 20-22 November 2012; pp. 1460-1463.

143. Leung, X.Y.; Wang, F.; Wu, B.; Bai, B.; Stahura, K.A.; Xie, Z. A Social Network Analysis of Overseas Tourist Movement Patterns in Beijing: The Impact of the Olympic Games. Int. J. Tour. Res. 2012, 14, 469-484, doi:10.1002/jtr.876. [CrossRef]

144. Baraglia, R.; Frattari, C.; Muntean, C.; Nardini, F.; Silvestri, F. A Trajectory-Based Recommender System for Tourism. In Proceedings of the 8th International Conference, Macau, China, 4-7 December 2012; Huang, R., Ghorbani, A., Pasi, G., Yamaguchi, T., Yen, N., Jin, B., Eds.; Springer: Berlin, Germany, 2012; pp. 196-205.

145. Kozicka, K.; Szopa, R. Managing of the tourist destinations offer based on the dynamics and the forecast of tourist movement. Pol. J. Manag. Stud. 2016, 14, 127-136, doi:10.17512/pjms.2016.14.2.12. [CrossRef]

146. Zakrisson, I.; Zillinger, M. Emotions in motion: Tourist experiences in time and space. Curr. Issues Tour. 2012, 15, 505-523, doi:10.1080/13683500.2011.615391. [CrossRef]

147. Xiao-Ting, H.; Bi-Hu, W. Intra-attraction Tourist Spatial-Temporal Behaviour Patterns. Tour. Geogr. 2012, 14, 625-645, doi:10.1080/14616688.2012.647322. [CrossRef]

148. Baraglia, R.; Frattari, C.; Muntean, C.; Nardini, F.; Silvestri, F. RecTour: A Recommender System for Tourists. In Proceedings of the 2012 IEEE/WIC/ACM International Joint Conferences on Web Intelligence and Intelligent Agent Technology (WI-IAT 2012), Macau, China, 4-7 December 2012.

149. Zheng, Y.T.; Zha, Z.J.; Chua, T.S. Mining Travel Patterns from Geotagged Photos. ACM Trans. Intell. Syst. Technol. 2012, 3, 56, doi:10.1145/2168752.2168770. [CrossRef]

150. Hallo, J.C.; Beeco, J.A.; Goetcheus, C.; McGee, J.; McGehee, N.G.; Norman, W.C. GPS as a Method for Assessing Spatial and Temporal Use Distributions of Nature-Based Tourists. J. Travel Res. 2012, 51, 591-606, doi:10.1177/0047287511431325. [CrossRef]

151. Parroco, A.M.; Vaccina, F.; De Cantis, S.; Ferrante, M. Multi-Destination Trips and Tourism Statistics: Empirical Evidences in Sicily. Economics 2012, 6, 12-27, doi:10.5018/economics-ejournal.ja.2012-44. [CrossRef]

152. Chen, T.; Pearce, P.L. Seasonality patterns in Asian tourism. Tour. Econ. 2012, 18, 1105-1115. [CrossRef]

153. Doscher, C.; Moore, K.; Smallman, C.; Wilson, J.; Simmons, D. An Agent-Based Model of Tourist Movements in New Zealand: Implications for Spatial Yield. In Proceedings of the 19th International Congress on Modelling and Simulation (MODSIM2011), Perth, Australia, 12-16 December 2011; pp. 2908-2913.

154. Shoval, N.; McKercher, B.; Birenboim, A.; Ng, E. The Application of a Sequence Alignment Method to the Creation of Typologies of Tourist Activity in Time and Space. Environ. Plan. B Plan. Des. 2015, 42, 76-94, doi:10.1068/b38065. [CrossRef]

155. Xia, J.C.; Zeephongsekul, P.; Packer, D. Spatial and temporal modelling of tourist movements using Semi-Markov processes. Tour. Manag. 2011, 32, 844-851, doi:10.1016/j.tourman.2010.07.009. [CrossRef]

156. Rastogi, R.; Chandra, S.; Vamsheedhar, J.; Das, V.R. Parametric Study of Pedestrian Speeds at Midblock Crossings. J. Urban Plan. Dev. ASCE 2011, 137, 381-389, doi:10.1061/(ASCE)UP.1943-5444.0000083. [CrossRef]

157. Li, C.; Zhao, Y.; Sun, X.; Su, X.; Zheng, S.; Dong, R.; Shi, L. Photography-based analysis of tourists' temporal-spatial behaviour in the Old Town of Lijiang. Int. J. Sustain. Dev. World Ecol. 2011, 18, 523-529, doi:10.1080/13504509.2011.601471. [CrossRef]

158. Dejbakhsh, S.; Arrowsmith, C.; Jackson, M. Cultural Influence on Spatial Behaviour. Tour. Geogr. 2011, 13, 91-111, doi:10.1080/14616688.2010.516396. [CrossRef]

159. Xia, J.C.; Evans, F.H.; Spilsbury, K.; Ciesielski, V.; Arrowsmith, C.; Wright, G. Market segments based on the dominant movement patterns of tourists. Tour. Manag. 2010, 31, 464-469. [CrossRef]

160. Terrier, C. Tourist Flows and Inflows: On Measuring Instruments and the Geomathematics of Flows. In Transport Survey Methods: Keeping up with a Changing World; Bonnel, P., LeeGosselin, M., Zmud, J., Madre, J.L., Eds.; Emerald Group Publishing Limited: Bingley, UK, 2009; pp. 219-241.

161. Xia, J.; Zeephongsekul, P. Space and Time Analysis of Tourist Movements using Semi-Markov Processes. In Proceedings of the 18th World Imacs Congress, Cairns, Australia, 13-17 July 2009; pp. 1265-1271. 
162. Weidenfeld, A.; Butler, R.W.; Williams, A.M. Clustering and compatibility between tourism attractions. Int. J. Tour. Res. 2010, 12, 1-16, doi:10.1002/jtr.732. [CrossRef]

163. Xia, J.; Packer, D.; Dong, C. Individual differences and tourist wayfinding behaviours. In Proceedings of the 18th World Imacs Congress, Cairns, Australia, 13-17 July 2009; pp. 1272-1278.

164. Xia, J.; Zeephongsekul, P.; Arrowsmith, C. Modelling spatio-temporal movement of tourists using finite Markov chains. Math. Comput. Simul. 2009, 79, 1544-1553. [CrossRef]

165. Bastianoni, S.; Pulselli, R.M.; Romano, P.; Pulselli, F.M. Dynamics and evolution of urban patterns: The evidence of the Mobile Landscape project. Des. Nat. IV Comp. Des. Nat. Sci. Eng. 2008, 4, 253-260.

166. Girardin, F.; Blat, J.; Calabrese, F.; Dal Fiore, F.; Ratti, C. Digital Footprinting: Uncovering Tourists with User-Generated Content. IEEE Pervasive Comput. 2008, 7, 36-43, doi:10.1109/MPRV.2008.71. [CrossRef]

167. McKercher, B.; Wong, C.; Lau, G. How tourists consume a destination. J. Bus. Res. 2006, 59, 647-652, doi:10.1016/j.jbusres.2006.01.009. [CrossRef]

168. Xia, J.; Arrowsmith, C. Managing Scale Issues in Spatio-temporal Movement of Tourists Modelling. In Proceedings of the International Congress on Modelling and Simulation (Modsim) 2005, Melbourne, Australia, 12-15 December 2005; pp. 162-169.

169. Klimek, R. Mapping Population and Mobile Pervasive Datasets into Individual Behaviours for Urban Ecosystems. In Proceedings of the International Conference on Artificial Intelligence and Soft Computing, Zakopane, Poland, 12-16 June 2016; pp. 683-694, doi:10.1007/978-3-319-39378-0 \_58. [CrossRef]

170. O'Connor, A.; Zerger, A.; Itami, B. Geo-temporal tracking and analysis of tourist movement. Math. Comput. Simul. 2005, 69, 135-150, doi:10.1016/j.matcom.2005.02.036. [CrossRef]

171. Hu, F.; Li, Z.; Yang, C.; Jiang, Y. A graph-based approach to detecting tourist movement patterns using social media data. Cartogr. Geogr. Inf. Sci. 2019, 46, 368-382, doi:10.1080/15230406.2018.1496036. [CrossRef]

172. Lee, H.; Chung, N.; Nam, Y. Do online information sources really make tourists visit more diverse places? Based on the social networking analysis. Inf. Process. Manag. 2019, 56, 1376-1390. [CrossRef]

173. Ruiz, J.B.; Lamers, M.; Bush, S.; Wells, G.B. Governing nature-based tourism mobility in National Park Torres del Paine, Chilean Southern Patagonia. Mobilities 2019, 1-17, doi:10.1080/17450101.2019.1614335. [CrossRef]

174. Mehmood, F.; Ahmad, S.; Kim, D. Design and Development of a Real-Time Optimal Route Recommendation System Using Big Data for Tourists in Jeju Island. Electronics 2019, 8, 506. [CrossRef]

175. Caldeira, A.M.; Kastenholz, E. Spatiotemporal tourist behaviour in urban destinations: A framework of analysis. Tour. Geogr. 2019, 1-29, doi:10.1080/14616688.2019.1611909. [CrossRef]

176. Zheng, W.; Zhou, R.; Zhang, Z.; Zhong, Y.; Wang, S.; Wei, Z.; Ji, H. Understanding the tourist mobility using GPS: How similar are the tourists? Tour. Manag. 2019, 71, 54-66.10.1016/j.tourman.2018.09.019. [CrossRef]

177. Klimek, R. Towards Recognising Individual Behaviours from Pervasive Mobile Datasets in Urban Spaces. Sustainability 2019, 11, 1563, doi:10.3390/su11061563. [CrossRef]

178. Li, Y.; Yang, L.; Shen, H.; Wu, Z. Modeling intra-destination travel behavior of tourists through spatio-temporal analysis. J. Destin. Mark. Manag. 2019, 11, 260-269.10.1016/j.jdmm.2018.05.002. [CrossRef]

179. Zhu, X.; Sun, T.; Yuan, H.; Hu, Z.; Miao, J. Exploring Group Movement Pattern through Cellular Data: A Case Study of Tourists in Hainan. ISPRS Int. J. Geo-Inf. 2019, 8, 74, doi:10.3390/ijgi8020074. [CrossRef]

180. Zai, C.; Lowen Sahr, C.L. touristic route as a tool for territorial development: The 'verde que te quero verde' route in campo Magro/Parana (Brasil). Finisterra Rev. Port. Geogr. 2019, 54, 135-154. [CrossRef]

181. Khairi, N.D.M.; Ismail, H.N.; Jaafar, S.M.R.S. Tourist behaviour through consumption in Melaka World Heritage Site. Curr. Issues Tour. 2019, 22, 582-600, doi:10.1080/13683500.2018.1491534. [CrossRef]

182. Qin, S.; Man, J.; Wang, X.; Li, C.; Dong, H.; Ge, X. Applying Big Data Analytics to Monitor Tourist Flow for the Scenic Area Operation Management. Discret. Dyn. Nat. Soc. 2019, 2019, 8239047. [CrossRef]

183. Duffy, A. Two-way street: How smartphones and the social web impact the travellers liminal gaze. Mob. Media Commun. 2019, 7, 60-75, doi:10.1177/2050157918772858. [CrossRef]

184. Van der Zee, E.; Bertocchi, D. Finding patterns in urban tourist behaviour: A social network analysis approach based on TripAdvisor reviews. Inf. Technol. Tour. 2018, 20, 153-180. [CrossRef]

185. Zhao, X.; Lu, X.; Liu, Y.; Lin, J.; An, J. Tourist movement patterns understanding from the perspective of travel party size using mobile tracking data: A case study of Xi'an, China. Tour. Manag. 2018, 69, 368-383, doi:10.1016/j.tourman.2018.06.026. [CrossRef]

186. Kidd, A.; D'Antonio, A.; Monz, C.; Heaslip, K.; Taff, D.; Newman, P. A GPS-Based Classification of Visitors Vehicular Behavior in a Protected Area Setting. J. Park Recreat. Adm. 2018, 36. [CrossRef] 
187. Matsuda, Y.; Fedotov, D.; Takahashi, Y.; Arakawa, Y.; Yasumoto, K.; Minker, W. EmoTour: Estimating Emotion and Satisfaction of Users Based on Behavioral Cues and Audiovisual Data. Sensors 2018, 18, 3978, doi:10.3390/s18113978. [CrossRef]

188. Zeng, B. Pattern of Chinese tourist flows in Japan: A Social Network Analysis perspective. Tour. Geogr. 2018, 20, 810-832, doi:10.1080/14616688.2018.1496470. [CrossRef]

189. Veretekhina, S.V.; Shmakova, E.G.; Medvedeva, V.A.; Makushkin, S.A.; Kashirin, V.S.; Pivneva, V.S. Identification Of Distrust Of The Functionality Of Mobile Applications. Suggestions For Personalization of the Data Provided By The Example Of Tourism. Mod. J. Lang. Teach. Methods 2018, 8, 147-154.

190. Kim, E.J.; Jo, Y.; Kang, Y. Are Touristic Attractions Well-Connected in an Olympic Host City? A Network Analysis Measurement of Visitor Movement Patterns in Gangneung, South Korea. Sustainability 2018, 10, 3310, doi:10.3390/su10093310. [CrossRef]

191. Cvelbar, L.K.; Mayr, M.; Vavpotic, D. Geographical mapping of visitor flow in tourism: A user-generated content approach. Tour. Econ. 2018, 24, 701-719. [CrossRef]

192. Vu, H.Q.; Li, G.; Law, R.; Zhang, Y. Tourist activity analysis by leveraging mobile social media data. J. Travel Res. 2018, 57, 883-898. [CrossRef]

193. Lee, Y.; Kim, I. Change and stability in shopping tourist destination networks: The case of Seoul in Korea. J. Destin. Mark. Manag. 2018, 9, 267-278. [CrossRef]

194. Kang, S.; Lee, G.; Kim, J.; Park, D. Identifying the spatial structure of the tourist attraction system in South Korea using GIS and network analysis: An application of anchor-point theory. J. Destin. Mark. Manag. 2018, 9, 358-370. [CrossRef]

195. Scherrer, L.; Tomko, M.; Ranacher, P.; Weibel, R. Travelers or locals? Identifying meaningful sub-populations from human movement data in the absence of ground truth. EPJ Data Sci. 2018, 7, 19. [CrossRef]

196. Jin, C.; Cheng, J.; Xu, J. Using user-generated content to explore the temporal heterogeneity in tourist mobility. J. Travel Res. 2018, 57,779-791. [CrossRef]

197. Bartie, P.; Mackaness, W.; Lemon, O.; Dalmas, T.; Janarthanam, S.; Hill, R.L.; Dickinson, A.; Liu, X. A dialogue based mobile virtual assistant for tourists: The SpaceBook Project. Comput. Environ. Urban Syst. 2018, 67, 110-123. [CrossRef]

198. Chung, H.; Chung, N.; Nam, Y. A social network analysis of tourist movement patterns in blogs: Korean backpackers in Europe. Sustainability 2017, 9, 2251. [CrossRef]

199. Taczanowska, K.; Bielański, M.; González, L.M.; Garcia-Massó, X.; Toca-Herrera, J. Analyzing spatial behavior of backcountry skiers in mountain protected areas combining GPS tracking and graph theory. Symmetry 2017, 9, 317. [CrossRef]

200. Shao, J.; Chang, X.; Morrison, A. How can big data support smart scenic area management? An analysis of travel blogs on Huashan. Sustainability 2017, 9, 2291. [CrossRef]

201. Zheng, W.; Liao, Z.; Qin, J. Using a four-step heuristic algorithm to design personalized day tour route within a tourist attraction. Tour. Manag. 2017, 62, 335-349. [CrossRef]

202. Hernández, J.M.; González-Martel, C. An evolving model for the lodging-service network in a tourism destination. Phys. A Stat. Mech. Appl. 2017, 482, 296-307. [CrossRef]

203. Miah, S.J.; Vu, H.Q.; Gammack, J.; McGrath, M. A big data analytics method for tourist behaviour analysis. Inf. Manag. 2017, 54, 771-785. [CrossRef]

204. Hardy, A.; Hyslop, S.; Booth, K.; Robards, B.; Aryal, J.; Gretzel, U.; Eccleston, R. Tracking tourists travel with smartphone-based GPS technology: A methodological discussion. Inf. Technol. Tour. 2017, 17, $255-274$. [CrossRef]

205. Liu, Y.; Ester, M.; Qian, Y.; Hu, B.; Cheung, D.W. Microscopic and macroscopic spatio-temporal topic models for check-in data. IEEE Trans. Knowl. Data Eng. 2017, 29, 1957-1970. [CrossRef]

206. Becker, M.; Lemmerich, F.; Singer, P.; Strohmaier, M.; Hotho, A. MixedTrails: Bayesian hypothesis comparison on heterogeneous sequential data. Data Min. Knowl. Discov. 2017, 31, 1359-1390. [CrossRef]

207. Liu, W.; Dong, C.; Chen, W. Mapping and quantifying spatial and temporal dynamics and bundles of travel flows of residents visiting urban parks. Sustainability 2017, 9, 1296. [CrossRef]

208. Zhang, Y.; Li, X.R.; Su, Q. Does spatial layout matter to theme park tourism carrying capacity? Tour. Manag. 2017, 61, 82-95. [CrossRef]

209. Peng, X.; Huang, Z. A novel popular tourist attraction discovering approach based on geo-tagged social media big data. ISPRS Int. J. Geo-Inf. 2017, 6, 216. [CrossRef] 
210. Pieraccini, M.; Betti, M.; Forcellini, D.; Dei, D.; Papi, F.; Bartoli, G.; Facchini, L.; Corazzi, R.; Kovacevic, V.C. Radar detection of pedestrian-induced vibrations on Michelangelo's David. PLoS ONE 2017, 12, e0174480. [CrossRef] [PubMed]

211. Zheng, W.; Huang, X.; Li, Y. Understanding the tourist mobility using GPS: Where is the next place? Tour. Manag. 2017, 59, 267-280. [CrossRef]

212. Ichifuji, Y.; Matsuo, Y.; Koide, N.; Akashi, N.; Terai, Y.; Kobayashi, T. A study for understanding of tourist person trip pattern based on log data of Wi-Fi access points. In Proceedings of the 2016 IEEE International Conference on Big Data (Big Data), Washington, DC, USA, 5-8 December 2016; pp. 2167-2174.

213. Hontus, A.C.; Alecu, I.N.; Cretu, R.F.; Cretu, R.C. Study Regarding the Tourist Traffic in the Danube Delta through Forecasting the Last Two Years. In Proceedings of the 27th International Business Information Management Association Conference, Milan, Italy, 4-5 May 2016; pp. 3592-3610.

214. Blečić, I.; Canu, D.; Cecchini, A.; Congiu, T.; Fancello, G.; Mauro, S.; Sacerdotti, S.L.; Trunfio, G.A. Coupling surveys with GPS tracking to explore tourists spatio-temporal behaviour. In Proceedings of the International Conference on Computational Science and Its Applications, Beijing, China, 4-7 July 2016; pp. 150-160.

215. Ivars, J.; Celdrán, M.; Triviño, A.; Vera-Rebollo, J. Tourist mobility at coastal mass destinations: Implications for sustainability. WIT Trans. Ecol. Environ. 2016, 201, 127-137.

216. Toha, M.A.M.; Ismail, H.N. A heritage tourism and tourist flow pattern: A perspective on traditional versus modern technologies in tracking the tourists. Int. J. Built Environ. Sustain. 2015, 2, 85-92.

217. Khairi, N.D.M.; Ismail, H.N. Acknowledging the Tourist Spatial Behavior for Space Management in Urban Heritage Destination. Int. J. Built Environ. Sustain. 2015, 2, 317-323. [CrossRef]

218. Sugimoto, K.; Koike, T. Tourist behaviors in the region at the foot of Mt. Fuji: An analysis focusing on the effect of travel distance. J. Geogr. Chigaku Zasshi 2015, 124, 1015-1031. [CrossRef]

219. Valle, D.; Cvetojevic, S.; Robertson, E.P.; Reichert, B.E.; Hochmair, H.H.; Fletcher, R.J. Individual movement strategies revealed through novel clustering of emergent movement patterns. Sci. Rep. 2017, 7, 44052. [CrossRef] [PubMed]

220. Liu, B.; Huang, S.S.; Fu, H. An application of network analysis on tourist attractions: The case of Xinjiang, China. Tour. Manag. 2017, 58, 132-141. [CrossRef]

221. Cortesi, N.; Gotti, K.; Psaila, G.; Burini, F.; Lwin, K.T.; Hossain, M. A network-based ranking approach to discover places visited by tourists from geo-located tweets. In Proceedings of the 2017 11th International Conference on Software, Knowledge, Information Management and Applications (SKIMA), Malabe, Sri Lanka, 6-8 December 2017; pp. 1-8.

222. Redin, D.; Vilela, D.; Nunes, N.; Ribeiro, M.; Prandi, C. ViTFlow: A platform to visualize tourists flows in a rich interactive map-based interface. In Proceedings of the 2017 Sustainable Internet and ICT for Sustainability (SustainIT), Funchal, Portugal, 6-7 December 2017; pp. 1-2.

223. Sobaś, E.; Gawroński, K.; Gawrońska, G.; Janus, B. Monitoring of Tourist Movement as a Basis for Management and Protection of Attractive Tourist Areas on the Example of the Popradzki Landscape Park. Acta Sci. Pol. Form. Circumiectus 2017, 16, 73. [CrossRef]

224. Zafar, A.; Kamran, M.; Shad, S.A.; Nisar, W. A Robust Missing Data-Recovering Technique for Mobility Data Mining. Appl. Artif. Intell. 2017, 31, 425-438. [CrossRef]

225. Nishad, A.; Abraham, S. Semantic trajectory analysis for identifying locations of interest of moving objects. In Proceedings of the 2017 International Conference on Networks \& Advances in Computational Technologies (NetACT), Thiruvanthapuram, India, 20-22 July 2017; pp. 257-261.

226. Lee, H.; Chung, N. Explorative Study on Movement Patterns of Korean Domestic Tourists Using Social Networking Analysis for Implementation of Smart Tourism Ecosystem. J. Korea Serv. Manag. Soc. 2017, 18, 57-74.

227. Anagnostopoulos, V.; Havlena, M.; Kiefer, P.; Giannopoulos, I.; Schindler, K.; Raubal, M. Gaze-Informed location-based services. Int. J. Geogr. Inf. Sci. 2017, 31, 1770-1797. [CrossRef]

228. Nezdoyminov, S.; Andryeyeva, N. Studies of tourist traffic on the water transport in Ukraine. Mark. Manag. Innov. 2017, 1, 205-212. [CrossRef]

229. Shoval, N.; Ahas, R. The use of tracking technologies in tourism research: The first decade. Tour. Geogr. 2016, 18, 587-606. [CrossRef]

230. Chua, A.; Servillo, L.; Marcheggiani, E.; Moere, A.V. Mapping Cilento: Using geotagged social media data to characterize tourist flows in southern Italy. Tour. Manag. 2016, 57, 295-310. [CrossRef] 
231. Luo, D.; Xu, H.; Zhen, Y.; Dilkina, B.; Zha, H.; Yang, X.; Zhang, W. Learning mixtures of markov chains from aggregate data with structural constraints. IEEE Trans. Knowl. Data Eng. 2016, 28, 1518-1531. [CrossRef]

232. Groß, S.; Menzel, A. GPS-Tracking in touristischen Destinationen-Neue Software-Anwendung zur Erfassung des Mobilitätsverhaltens am Beispiel von Wanderern im Harz. Raumforsch. Raumordn. 2016, 74, 51-68. [CrossRef]

233. Thimm, T.; Seepold, R. Past, present and future of tourist tracking. J. Tour. Futures 2016, 2, 43-55. [CrossRef]

234. Li, Y.; Xiao, L.; Ye, Y.; Xu, W.; Law, A. Understanding tourist space at a historic site through space syntax analysis: The case of Gulangyu, China. Tour. Manag. 2016, 52, 30-43. [CrossRef]

235. Baerenholdt, J.O. Experiencing the enchantment of place and mobility. J. Consum. Cult. 2016, 16, 393-411, doi:10.1177/1469540516635415. [CrossRef]

236. Roura, R.M. Being there: Examining the behaviour of Antarctic tourists through their blogs. Polar Res. 2012, 31, 10905, doi:10.3402/polar.v31i0.10905. [CrossRef]

237. Zhang, J.; Wu, W.; Gao, H.; Zhang, Y. Design of monitoring and management system of tourist attractions based on RFID technology. In Proceedings of the 2012 IEEE Symposium on Robotics and Applications (ISRA), Kuala Lumpur, Malaysia, 3-5 June 2012; pp. 773-776.

238. Lucchese, C.; Perego, R.; Silvestri, F.; Vahabi, H.; Venturini, R. How random walks can help tourism. In Proceedings of the 34th European Conference on IR Research (ECIR 2012), Barcelona, Spain, 1-5 April 2012; pp. 195-206.

239. Vaccari, A.; Liu, L.; Biderman, A.; Ratti, C.; Pereira, F.; Oliveirinha, J.; Gerber, A. A holistic framework for the study of urban traces and the profiling of urban processes and dynamics. In Proceedings of the 2009 12TH International IEEE Conference on Intelligent Transportation Systems (ITSC 2009), St Louis, MO, USA, 4-7 October 2009; pp. 273-278.

240. Chareyron, G.; Da-Rugna, J.; Branchet, B. Mining tourist routes using flickr traces. In Proceedings of the 2013 IEEE/ACM International Conference on Advances in Social Networks Analysis and Mining, Niagara, ON, Canada, 25-28 August 2013; pp. 1488-1489.

241. Önder, I.; Koerbitz, W.; Hubmann-Haidvogel, A. Tracing tourists by their digital footprints: The case of Austria. J. Travel Res. 2016, 55, 566-573. [CrossRef]

242. Phithakkitnukoon, S.; Horanont, T.; Witayangkurn, A.; Siri, R.; Sekimoto, Y.; Shibasaki, R. Understanding tourist behavior using large-scale mobile sensing approach: A case study of mobile phone users in Japan. Pervasive Mob. Comput. 2015, 18, 18-39, doi:10.1016/j.pmcj.2014.07.003. [CrossRef]

243. Paldino, S.; Bojic, I.; Sobolevsky, S.; Ratti, C.; González, M.C. Urban magnetism through the lens of geo-tagged photography. EPJ Data Sci. 2015, 4, 5. [CrossRef]

244. Bordogna, G.; Frigerio, L.; Cuzzocrea, A.; Psaila, G. Clustering geo-tagged tweets for advanced big data analytics. In Proceedings of the 2016 IEEE International Congress on Big Data (BigData Congress), San Francisco, CA, USA, 27 June-2 July 2016; pp. 42-51.

245. Hasnat, M.M.; Hasan, S. Identifying tourists and analyzing spatial patterns of their destinations from location-based social media data. Transp. Res. Part C Emerg. Technol. 2018, 96, 38-54. [CrossRef]

246. Hawelka, B.; Sitko, I.; Kazakopoulos, P.; Beinat, E. Collective prediction of individual mobility traces for users with short data history. PLOS ONE 2017, 12, e0170907. [CrossRef]

247. Dou, L.; Qu, H.; Bi, X.; Zhang, Y.; Yu, C.; Qin, J.; Huang, X.; Li, X. MyTrace: A Mobile Phone Based Tourist Spatial Temporal Behavior Record and Analysis System. In Proceedings of the Monterey Workshop, Beijing, China, 8-11 October 2016; pp. 99-108.

248. Wang, L.-C.; Yan, C.-X.; Wang, J. The Research on Spatial temporal Characteristics of Tourist Flow in Lanzhou Based on Sina Microblog Big Data. DEStech Trans. Econ. Bus. Manag. 2016. [CrossRef]

249. Chiu, C.S.; Cheng, C.C.; Lin, Y.C. Multi dimensional spatio temporal data model Application to tourism guidance system of cultural resources. In Proceedings of the 2017 Pacific Neighborhood Consortium Annual Conference and Joint Meetings (PNC), Tainan, Taiwan, 7-9 November 2017; pp. 122-127.

250. Clarke, A.; Raffay, A.; Beritelli, P.; Wittmer, A. Supporting Mobility: Evaluating Mobile Technology Advances in Tourism. Tour. Anal. 2009, 14, 425-441, doi:10.3727/108354209X12596287114093. [CrossRef]

251. Cantis, S.D.; Ferrante, M.; Kahani, A.; Shoval, N. Cruise passengers' behavior at the destination: Investigation using GPS technology. Tour. Manag. 2016, 52, 133-150, doi:10.1016/j.tourman.2015.06.018. [CrossRef]

252. McKercher, B.; Shoval, N.; Park, E.; Kahani, A. The Limited Impact of Weather on Tourist Behavior in an Urban Destination. J. Travel Res. 2015, 54, 442-455, doi:10.1177/0047287514522880. [CrossRef] 
253. Bauder, M.; Freytag, T. Visitor mobility in the city and the effects of travel preparation. Tour. Geogr. 2015, 17, 682-700, doi:10.1080/14616688.2015.1053971. [CrossRef]

254. Yun, H.J.; Park, M.H. Time-Space Movement of Festival Visitors in Rural Areas Using a Smart Phone Application. Asia Pac. J. Tour. Res. 2015, 20, 1246-1265, doi:10.1080/10941665.2014.976581. [CrossRef]

255. Tiwari, S.; Kaushik, S. Modeling Personalized Recommendations of Unvisited Tourist Places Using Genetic Algorithms. In Databases in Networked Information Systems; Springer: Cham, Switzerland, 2015; pp. 264-276.

256. Cuzzocrea, A.; Psaila, G.; Toccu, M. Knowledge Discovery from Geo-Located Tweets for Supporting Advanced Big Data Analytics: A Real-Life Experience. In Proceedings of the Model and Data Engineering: 5th International Conference, MEDI 2015, Rhodes, Greece, 26-28 September 2015; pp. 285-294, doi:10.1007/978-3-319-23781-7_23. [CrossRef]

257. Spangenberg, T. Development of a mobile toolkit to support research on human mobility behavior using GPS trajectories. Inf. Technol. Tour. 2014, 14, 317-346, doi:10.1007/s40558-014-0005-9. [CrossRef]

258. Bermingham, L.; Lee, I. Spatio temporal Sequential Pattern Mining for Tourism Sciences. Procedia Comput. Sci. 2014, 29, 379-389, doi:10.1016/j.procs.2014.05.034. [CrossRef]

259. Tussyadiah, I.; Fesenmaier, D. Interpreting tourist experiences from firstperson stories: A foundation for mobile guides. In Proceedings of the 15th European Conference on Information Systems, St. Gallen, Switzerland, 7-9 June 2007; pp. 2259-2270.

260. Moller-Jensen, L. Spatial narratives from mobile GIS-The case of H.C.Andersen in Copenhagen. Kart Plan 2017, 67, 176-182.

261. Haldrup, M. Laid-back mobilities: Second-home holidays in time and space. Tour. Geogr. 2004, 6, 434-454, doi:10.1080/1461668042000280228. [CrossRef]

262. Chardonnel, S.; Van der Knaap, W. Managing tourist time-space movements in recreational areas: A comparative study of a protected natural park in the French Alps and the "De Hoge Veluwe" Dutch National Park using the same methodology. Rev. Geogr. Alp. 2002, 90, 37-48. [CrossRef]

263. Debbage, K. Activity Spaces in New Environments: Tourist Movements in a Resort Setting in the Bahamas. Ph.D. Thesis, University of Georgia, Athens, GA, USA, 1988.

264. Cooper, C. Spatial and temporal patterns of tourist behaviour. Reg. Stud. 1981, 15, 359-371. [CrossRef]

265. Warszynska, J. The application of the simulation method 'Monte Carlo' to forecast spatial distribution of tourist movement. Folia Geogr. Ser. Geogr. Oeconomica 1980, 13, 73-84.

266. Cai, G.; Lee, K.; Lee, I. A framework for mining semantic-level tourist movement behaviours from geo-tagged photos. In Australasian Joint Conference on Artificial Intelligence; Springer: Cham, Switzerland, 2016; pp. 519-524.

267. Zhong, L.; Sun, S.; Law, R. Movement patterns of tourists. Tour. Manag. 2019, 75, 318-322, doi:10.1016/j.tourman.2019.05.015. [CrossRef]

268. Mansouri, M.; Ujang, N. Space syntax analysis of tourists movement patterns in the historical district of Kuala Lumpur, Malaysia. J. Urban. Int. Res. Placemaking Urban Sustain. 2017, 10, 163-180. [CrossRef]

269. Caldeira, A.M.; Kastenholz, E. Its so hot: Predicting climate change effects on urban tourists time-space experience. J. Sustain. Tour. 2018, 26, 1516-1542. [CrossRef]

270. Mckercher, B.; Hardy, A.; Aryal, J. Using tracking technology to improve marketing: Insights from a historic town in Tasmania, Australia. J. Travel Tour. Mark. 2019, 36, 1-12. [CrossRef]

271. Brilhante, I.R.; Macedo, J.A.; Nardini, F.M.; Perego, R.; Renso, C. On planning sightseeing tours with TripBuilder. Inf. Process. Manag. 2015, 51, 1-15, doi:10.1016/j.ipm.2014.10.003. [CrossRef]

272. Anu, J.; Agrawal, R.; Bhattacharya, S. Ranking tourist attractions using time series GPS data of cabs. In Proceedings of the IEEE Southeastcon 2014, Lexington, KY, USA, 13-16 March 2014; pp. 1-6, doi:10.1109/SECON.2014.6950659. [CrossRef]

273. Vu, H.Q.; Li, G.; Law, R.; Ye, B.H. Exploring the travel behaviors of inbound tourists to Hong Kong using geotagged photos. Tour. Manag. 2015, 46, 222-232, doi:10.1016/j.tourman.2014.07.003. [CrossRef]

274. Chen, C. CiteSpace II: Detecting and visualizing emerging trends and transient patterns in scientific literature. J. Am. Soc. Inf. Sci. Technol. 2006, 57, 359-377. [CrossRef]

275. Harzing, A.W.; Van der Wal, R. Google Scholar: The democratization of citation analysis. Ethics Sci. Environ. Politics 2007, 8, 61-73. [CrossRef]

276. McKercher, B.; Shoval, N.; Ng, E.; Birenboim, A. First and Repeat Visitor Behaviour: GPS Tracking and GIS Analysis in Hong Kong. Tour. Geogr. 2012, 14, 147-161, doi:10.1080/14616688.2011.598542. [CrossRef] 
277. McKercher, B.; Zoltan, J. Tourist Flows and Spatial Behavior. In The Wiley Blackwell Companion to Tourism; John Wiley \& Sons, Ltd.: Hoboken, NJ, USA, 2014; pp. 33-44, doi:10.1002/9781118474648.ch2.

278. Shoval, N. Monitoring and Managing Visitors Flows in Destinations using Aggregative GPS Data. In Information and Communication Technologies in Tourism 2010; Gretzel, U., Law, R., Fuchs, M., Eds.; Springer: Vienna, Austria, 2010; pp. 171-183, doi:10.1007/978-3-211-99407-8_15.

279. Edwards, D.; Griffin, T.; Hayllar, B. Urban Tourism Research: Developing an Agenda. Ann. Tour. Res. 2008, 35, 1032-1052, doi:10.1016/j.annals.2008.09.002. [CrossRef]

280. Ahas, R.; Saluveer, E.; Tiru, M.; Silm, S. Mobile Positioning Based Tourism Monitoring System: Positium Barometer. In Information and Communication Technologies in Tourism 2008; OConnor, P., Hopken, W., Gretzel, U., Eds.; Springer: Vienna, Austria, 2008; pp. 475-485, doi:10.1007/978-3-211-77280-5_42.

281. Ahas, R.; Aasa, A.; Roose, A.; Mark, U.; Silm, S. Evaluating passive mobile positioning data for tourism surveys: An Estonian case study. Tour. Manag. 2008, 29, 469-486. [CrossRef]

282. Leiper, N. Tourism Management; RMIT Press: Melbourne, Australia, 1997.

283. Dietvorst, A.; Ashworth, G. Tourism Transformations: An Introduction; CABI: Wallingford, UK, 1995; pp. 1-12.

284. Richards, G.; Raymond, C. Creative tourism. ATLAS News 2000, 23, 16-20.

285. Aranburu, I.; Plaza, B.; Esteban, M. Sustainable Cultural Tourism in Urban Destinations: Does Space Matter? Sustainability 2016, 8, 699. [CrossRef]

286. Espelt, N.G.; Benito, J.A.D. First-time versus repeat visitors behavior patterns: A GPS analysis. Bol. Asoc. Geogr. Esp. 2018, 78, 49-65.

287. Yun, H.J.; Kang, D.J.; Lee, M.J. Spatiotemporal distribution of urban walking tourists by season using GPS-based smartphone application. Asia Pac. J. Tour. Res. 2018, 23, 1047-1061. [CrossRef]

288. Miyasaka, T.; Oba, A.; Akasaka, M.; Tsuchiya, T. Sampling limitations in using tourists mobile phones for GPS-based visitor monitoring. J. Leis. Res. 2018, 49, 298-310. [CrossRef]

289. Versichele, M.; de Groote, L.; Bouuaert, M.C.; Neutens, T.; Moerman, I.; de Weghe, N.V. Pattern mining in tourist attraction visits through association rule learning on Bluetooth tracking data: A case study of Ghent, Belgium. Tour. Manag. 2014, 44, 67-81, doi:10.1016/j.tourman.2014.02.009. [CrossRef]

290. Ros, M.; D'Souza, M.; Postula, A.; MacColl, I. Location based services with personal area network for community and tourism applications. In Proceedings of the IET International Communication Conference on Wireless Mobile and Computing (CCWMC 2011), Shanghai, China, 14-16 November 2011; pp. 432-437, doi:10.1049/cp.2011.0924. [CrossRef]

291. Cui, Y.; Mahoney, E. Employing Internet GIS Surveys to Characterize Recreational Boating Travel Patterns. Trans. GIS 2015, 19, 42-62, doi:10.1111/tgis.12079. [CrossRef]

292. Black, W.R. Sustainable transportation: A US perspective. J. Transp. Geogr. 1996, 4, 151-159. [CrossRef]

293. Gössling, S.; Scott, D.; Hall, C.M.; Ceron, J.P.; Dubois, G. Consumer behaviour and demand response of tourists to climate change. Ann. Tour. Res. 2012, 39, 36-58, doi:10.1016/j.annals.2011.11.002. [CrossRef]

(C) 2019 by the authors. Licensee MDPI, Basel, Switzerland. This article is an open access article distributed under the terms and conditions of the Creative Commons Attribution (CC BY) license (http:/ / creativecommons.org/licenses/by/4.0/). 